\title{
U.S. INCOME, SAVING, AND WEALTH, 1929-1969
}

\author{
By Laurits R. Christensen and Dale W. Jorgenson* \\ University of Wisconsin and Harvard University
}

\begin{abstract}
The objective of this paper is to present income and expenditure accounts, accumulation accounts, and the asset side of the wealth accounts for the U.S. private national economy in current and constant prices. These accounts are integrated with the production and factor outlay accounts for the U.S. private domestic economy in current and constant prices given in our earlier papers. Taken together, these accounts constitute a complete accounting system in current and constant prices for the private sector of the U.S. economy.

Our complete accounting system incorporates a new concept of the standard of living, defined as the ratio of the quantity index of gross private national expenditures to the quantity index of gross private national consumer receipts. Our concept of the standard of living is similar but not identical to our concept of total factor productivity. Changes in the private standard of living reflect both changes in total factor productivity and changes in the proportion of the total product consumed in the public sector.
\end{abstract}

\section{INTRODUCTION}

In two previous papers we have presented production and factor outlay accounts for the U.S. private domestic economy in current and constant prices. ${ }^{1}$ These accounts include a measure of real product and a measure of real factor input. The ratio between the two is a measure of total factor productivity. Relative to conventional measures our production accounts assign greater importance to capital accumulation and less importance to total factor productivity as sources of economic growth. The main implication of our results is that greater emphasis is required on the sources and uses of saving in accounting for economic growth.

In this paper we extend the accounting system developed in our earlier papers to include saving and its uses. We present income and expenditure accounts, giving data on factor incomes, expenditures, and saving for the U.S. private national economy. In addition, we give an accumulation account, allocating saving to its various uses and a wealth account giving data on assets accumulated through saving. A complete accounting system includes production and factor outlay accounts, income and expenditure accounts, accumulation accounts, and wealth accounts.

In view of the importance of the separation of changes in accounting magnitudes into price and quantity components, it is not surprising that much attention has been given to the measurement of real magnitudes. However, only the measures of real product and real assets are well established in accounting

* Christensen is Associate Professor of Economics at the University of Wisconsin. He was on leave at the Office of Prices, U.S. Bureau of Labor Statistics, when this paper was written. Jorgenson is Professor of Economics at Harvard University.

The authors are grateful to Brenda Erickson, Victoria Farrell, and Gary Robbins for assistance with the research. Financial support for this research was provided by the National Science Foundation through Grant GS-36945 to the University of Wisconsin and Grant GS2802 to Harvard University.

${ }^{1}$ See Christensen and Jorgenson $(1969,1970)$. 
practice. In the analysis of sources of economic growth, measures of factor input, income, expenditure, saving, and capital formation in both current and constant prices are essential. These measures must be integrated with measures of real product and real wealth in a complete accounting system.

We present income and expenditure accounts, accumulation accounts, and the asset side of the wealth accounts for the U.S. private national economy in current and constant prices. These accounts are integrated with the production and factor outlay accounts for the U.S. private domestic economy in current and constant prices given in our earlier papers. Taken together, these accounts constitute a complete accounting system in current and constant prices for the private sector of the U.S. economy.

In Section 2 we present accounts for U.S. gross private national consumer receipts and expenditures in current prices. We first define income and compare our definition with other income concepts. We then allocate income between labor and property compensation. We allocate expenditures between consumer outlays and saving. In Section 3 we divide consumption expenditures between price and quantity components. In Sections 4 and 5 we divide labor and property income into price and quantity components.

The fundamental accounting identity for the income and expenditure account is that consumer receipts are equal to consumer outlays plus saving. The income and expenditure account is linked directly to the production account through factor income and consumer expenditures. Factor outlay by the private domestic sector is one component of factor income of the U.S. private national economy. Expenditure on consumption is one component of the output of goods and services by the production sector of the U.S. private domestic economy.

In Section 6 we present accounts for U.S. gross private national capital formation, revaluation, and saving. We divide capital formation, revaluation, and saving into price and quantity components. We combine quantity indexes of consumer outlays and capital formation into a quantity index of total expenditures. The fundamental accounting identity for the accumulation account is that saving is equal to capital formation. The accumulation account is linked to the production account through capital formation. Capital formation includes expenditures on investment goods.

In Section 7 we link capital formation and revaluation to the asset side of the wealth account for the U.S. private national economy. We separate wealth into tangible assets of the private sector and claims on the government and rest of world sectors by the private sector. Total wealth is the sum of private domestic tangible assets and net claims against the government and rest of world sectors. We present accounts for U.S. private national wealth in both current and constant prices.

Through the accumulation account, production, income, and expenditure are linked to the wealth account. The change in wealth from period to period is equal to capital formation less depreciation plus the revaluation of assets. The accumulation account is also linked to production through net capital formation, defined as capital formation less replacement. Net capital formation is related to changes in capital input in the production account, while net saving is related to changes in wealth. 
Our complete accounting system incorporates a new concept of the standard of living, defined as the ratio of the quantity index of gross private national expenditures to the quantity index of gross private national consumer receipts. Our concept of the standard of living is similar but not identical to our concept of total factor productivity. Changes in the private standard of living reflect both changes in total factor productivity and changes in the proportion of the total product consumed in the public sector.

\section{INCOME AND EXPENDITURE}

\subsection{Introduction}

The income and expenditure account includes data on the value of income from factor services and transfer payments, the value of consumer outlays and saving. The value of consumer receipts is equal to consumer outlays plus saving. The two sides of the receipts and expenditure account are linked through property compensation and saving. Saving results in the accumulation of tangible assets and financial claims; accumulated assets generate future property income. Saving must be defined in a way that is consistent with property compensation. Income must include all payments for factor services that result in consumption expenditures or in the accumulation of assets that result in future income.

Our accounting unit is the private national U.S. economy. We include as income all items which accrue to this sector whether or not they are available for current consumption. We include gross property income generated in the private domestic economy even if it is not completely distributed to individual consumers in the form of dividends and interest. Similarly we include contributions to social insurance in income. Our concept of income differs in several respects from personal disposable income, but is very similar to the concept of income implicit in the definition of gross private saving, as employed in the U.S. national accounts. ${ }^{2}$ We term our income concept gross private national income.

\subsection{Definition of Income}

We define income to include all payments for factor services provided by U.S. residents and income from financial claims on government and rest of world sectors by U.S. residents. We consolidate U.S. households, private businesses, and institutions into a single accounting unit. Financial claims on the business sector by households and institutions are liabilities of the business sector; in the consolidated account these assets and liabilities cancel out. We treat social insurance funds as part of the private national economy; contributions to social insurance funds are included and benefits paid from social insurance funds are excluded from gross private national income.

We define gross private national income to include property and labor income generated in the private domestic economy, net of interest paid by consumers, plus net property income of U.S. residents and businesses from the

${ }^{2}$ All references to data from the U.S. national income and product accounts are to The National Income and Product Accounts of the United States, 1929-1965, Statistical Tables, A Supplement to the Survey of Current Business, August 1966, henceforward NIP (1966), and subsequent national income issues of the Survey of Current Business, unless other wise indicated. 
foreign sector, plus labor income of U.S. residents from the foreign sector, plus labor compensation and net interest paid by government, all net of taxes, plus investment income of social insurance funds less transfers to general government by these funds. Transfer payments to persons other than benefits from social insurance funds are received by the private national economy from the government sector without any factor services being rendered. Thus these transfer payments are not included in our definition of income. Adding these transfers to gross private national income yields gross private national receipts. Gross private national income and gross private national receipts are presented for 1958 in Table 1.

\section{TABLE 1}

Gross Private National Receipts and Expenditures, 1958 (Current Prices)

\begin{tabular}{|c|c|c|}
\hline \multicolumn{3}{|c|}{ Receipts } \\
\hline 1. & Gross private domestic factor outlay ${ }^{a}$ & 419.7 \\
\hline 2. & + Income originating in general government (Table 1.13$)^{b}$ & 42.1 \\
\hline 3. & + Income originating in government enterprises (Table 1.13) & 4.8 \\
\hline 4. & + Income originating in rest of world (Table 1.13) & 2.0 \\
\hline 5. & + Investment income of social insurance funds (Table 3.7 ) & 1.8 \\
\hline 6. & - Transfers to general government from social insurance funds (Table 3.7) & 0.6 \\
\hline 7. & + Net interest paid by government (Tables 3.1 and 3.3 ) & 6.2 \\
\hline 8. & - Corporate profits tax liability (Table 1.10 ) & 19.0 \\
\hline 9. & - Business property taxes ${ }^{c}$ & 17.4 \\
\hline 10. & - Personal tax and nontax payments (Table 2.1 ) & 42.3 \\
\hline 11. & + Personal nontax payments (Tables $3.1,3.3$ ) & 2.3 \\
\hline 12. & $=$ Gross private national income & 399.5 \\
\hline 13. & $\begin{array}{l}\text { + Government transfer payments to persons other than benefits from social } \\
\text { insurance funds (Table } 3.9 \text { ) }\end{array}$ & 8.1 \\
\hline 14. & $=$ Gross private national consumer receipts & 407.7 \\
\hline \multicolumn{3}{|c|}{ Expenditures } \\
\hline 1. & Personal consumption expenditures (Table 1.1) & 290.1 \\
\hline 2. & - Personal consumption expenditures, durable goods (Table 1.1) & 37.9 \\
\hline 3. & + Services of consumer durables (our imputation) ${ }^{d}$ & 40.3 \\
\hline 4. & + Services of institutional durables (our imputation) ${ }^{d}$ & 0.3 \\
\hline 5 . & + Net rent on institutional real estate (our imputation) ${ }^{e}$ & 0.8 \\
\hline 6. & $=$ Private national consumption expenditure & 293.6 \\
\hline 7. & + Personal transfer payments to foreigners (Table 2.1) & 0.6 \\
\hline 8. & + Personal nontax payments (Tables $3.1,3.3$ ) & 2.3 \\
\hline 9. & $=$ Private national consumer outlays & 296.5 \\
\hline 10. & + Gross private national saving ${ }^{f}$ & 111.2 \\
\hline 11. & $=$ Private national expenditures & 407.7 \\
\hline
\end{tabular}

${ }^{a}$ Christensen and Jorgenson (1970, Table 1, p. 23). This series has been revised to include a net rent imputation to institutional structures. Also our other imputations have been slightly modified. See expenditure items 3, 4, and 5 below.

${ }^{b}$ All table references are to The National Income and Product Accounts of the United States, 1929-65, Statistical Tables, A Supplement to the Survey of Current Business, August 1966, henceforward NIP, 1966.

${ }^{\circ}$ Christensen and Jorgenson (1970, Table 1, p. 23, line 6 in factor outlay).

${ }^{d}$ Christensen and Jorgenson (1970, Section 5).

${ }^{e}$ We have computed an implicit rental value for institutional structures and land based on our estimate of the rate of return to owner-occupied real estate. The net rent figure is the difference between the implicit rental value and the "space rental value" (NIP, 1966, Table 7.3). This imputation was suggested to us by Edward F. Denison.

${ }^{f}$ See below, Table 3, line 5 . 
Our definition of private national consumption expenditures differs slightly from personal consumption expenditures. ${ }^{3}$ We exclude purchases of consumer durables and include imputations for services from consumer durables, institutional durables, and the equity return to institutional real estate. We preserve the usual accounting identity that consumer outlays plus saving equals consumer receipts. We define gross private national saving as gross private national consumer receipts less private national consumer outlays. Our estimates of consumer outlays and saving for 1958 are given in Table 1.

Our definition of income is similar to the widely used concept of personal disposal income, ${ }^{4}$ but there are several important differences. First, personal disposable income includes government transfer payments to persons and excludes contributions to social insurance funds. Since we include social insurance funds in the private national economy, we include contributions to social insurance in income but exclude benefits from social insurance funds; we treat other transfer payments as nonincome receipts. In addition we include the investment income of social insurance funds net of transfers to general government in gross private national income. These differences between gross private income and personal disposable income can be summarized as the surplus of social insurance funds plus government transfers to persons other than social insurance benefits. The surplus of social insurance funds is included in private saving and in gross private national income. Similarly wage accruals less disbursements are included in gross private national income.

Second, we include undistributed corporate profits, the corporate inventory valuation adjustment, capital consumption allowances for corporate, noncorporate, owner-occupied, and institutional tangible assets, and the statistical discrepancy in gross private national income. The statistical discrepancy is included so that the income and product accounts balance. The remaining items are included in income because they are part of gross private national saving. Third, our imputations for consumer durables, institutional durables, and the equity return on institutional real estate are included in gross private national income but not in personal disposable income. These flows of services are included in consumer expenditure and must also be included in income. Finally, we exclude net interest paid by consumers in order to have a symmetric treatment of interest received and interest paid by consumers. Table 2 contains a reconciliation of personal disposable income and our concept of gross private national income.

There are three differences between gross private national income, as we define it, and the concept of income implicit in the concept of gross private saving employed in the U.S. national income and product accounts. ${ }^{5}$ First, our imputations for services from consumer durables and institutional tangible assets are not included in the U.S. national accounts concept. Second, social insurance contributions and benefits are treated as in the U.S. national accounts in the manner described above for personal disposable income. Third, the statistical discrepancy is excluded. Since the underlying income concepts are

\footnotetext{
${ }^{3} N I P$ (1966), Table 1.1 .

${ }^{4} N I P$ (1966), Table 2.1.

${ }^{5}$ NIP (1966), Table 5.1.
} 
very close, our definition of gross private national saving is similar to that of gross private saving in the U.S. national accounts. A reconciliation of the two concepts is presented in Table 3 .

TABLE 2

Reconciliation of Personal Disposable Income and Gross Private NATIONAL INCOME, 1958

\begin{tabular}{|c|c|c|}
\hline 1. & Personal disposable income (Table 2.1$)^{a}$ & 318.8 \\
\hline 2. & - Surplus of social insurance funds (Table 3.7 ) & 0.0 \\
\hline 3. & $\begin{array}{l}\text { - Government transfer payments to persons other than benefits from social } \\
\text { insurance funds (Table 3.9) }\end{array}$ & 8.1 \\
\hline 4. & $\begin{array}{l}+ \text { Undistributed corporate profits and inventory valuation adjustment } \\
\text { (Table } 1.14)\end{array}$ & 10.5 \\
\hline 5 . & + Capital consumption allowances (Table 1.9) & 38.9 \\
\hline 6. & + Statistical discrepancy (Table 1.9) & 1.6 \\
\hline 7. & + Expenditure (items 3, 4, 5 from Table 1 above) & 41.4 \\
\hline 8 . & + Wage accruals less disbursements (Table 1.9) & 0.0 \\
\hline 9. & - Net interest paid by consumers (Table 2.1 ) & 5.9 \\
\hline 10. & + Personal nontax payments (Tables $3.1,3.3$ ) & 2.3 \\
\hline 11. & $=$ Gross private national income & 399.5 \\
\hline
\end{tabular}

${ }^{a}$ All table references are to The National Income and Product Accounts of the United States, 1929-65, Statistical Tables, A Supplement to the Survey of Current Business, August 1966, henceforward NIP, 1966.

TABLE 3

Reconciliation of Gross Private Saving and Gross Private NATIONAL SAVING, 1958

\begin{tabular}{lr}
\hline \hline & \\
1. & Gross private saving (Table 5.1) \\
1. & 71.7 \\
+ Personal consumption expenditures, durable goods (Table 1.1) & 37.9 \\
$3 . \quad+$ Surplus, social insurance funds (Table 3.7) & 0.0 \\
4. + Statistical discrepancy (Table 1.9) & 1.6 \\
$5 . \quad$ Gross private national saving & 111.2
\end{tabular}

${ }^{a}$ All table references are to The National Income and Product Accounts of the United States. 1929-65, Statistical Tables, A Supplement to the Survey of Current Business, August 1966, henceforward NIP, 1966.

\subsection{Labor and Property Compensation}

We divide total gross private national income between labor and capital income. The allocation of gross private domestic factor outlay between labor and capital is described in detail in Christensen and Jorgenson. ${ }^{6}$ We have maintained that allocation except for our treatment of entrepreneurial income. We follow Christensen ${ }^{7}$ in imputing the average annual wage of all employees in the private domestic economy to all proprietors. Christensen has shown that this imputation is consistent with the view that entrepreneurs receive competitive returns to both their labor and capital services.

${ }^{6}$ Christensen and Jorgenson (1970), Section 2, pp. $20-24$.

${ }^{7}$ Christensen (1971). 
The component of income originating in general government, government enterprises, and the rest of world sectors consisting of compensation of employees is allocated to labor income. Income originating in the rest of world sector consists of compensation of employees, ${ }^{8}$ which we assign to labor income, and corporate profits and net interest, which we assign to property income. The investment income of social insurance funds less transfers to general government and net interest paid by government are included in property income. The corporate profits tax and business property taxes are also allocated to property income.

Finally, we allocate personal income taxes between labor and property income in accord with a method developed by Frane and Klein. They describe their method as follows: "The fraction of taxes in each income bracket allocated to wage income is estimated by the ratio of wage and salary income to "adjusted gross income" in each bracket. Total taxes allocated to wages are the sum of the taxes so allocated in all brackets." "This method has been applied by Ando and Brown to U.S. data for 1929 to $1958 .{ }^{10}$ We have updated their figures to 1969 in a way that closely approximates this procedure.

TABLE 4

Gross Private National Labor and Property Compensation, 1958 (Current Prices)

\footnotetext{
Labor Compensation

1. Private domestic outlay for labor services (Table 6.1 plus our imputation for proprietors $)^{a}$

2. + Income originating in general government (Table 1.13)

3. + Income originating in government enterprises (Table 1.13)

4. + Compensation of employees, rest of world (Table 1.13)

5. - Personal income taxes attributed to labor income (our imputation)

6. = Private national labor income

1. Gross private domestic outlay for capital services (our imputation)

2. + Corporate profits, rest of world (Table 1.13)

3. + Net interest, rest of world (Table 1.13)

4. + Investment income of social insurance funds less transfers to general government (Table 3.7)

5. + Net interest paid by government (Tables 3.1 and 3.3)

6. - Corporate profits tax liability (Table 6.14)

7. - Business property taxes

8. - Personal income taxes attributed to property income (our imputation)

9. - Federal estate and gift taxes (Table 3.1)

10. - State and local death and gift taxes (Table 3.3)

11. - State and local government motor vehicle licenses, property taxes, and other taxes (Table 3.3)

12. = Gross private national property income

${ }^{a}$ All table references are to The National Income and Product Accounts of the United States, 1929-65, Statistical Tables, A Supplement to the Survey of Current Business, August 1966.

${ }^{b}$ Christensen and Jorgenson (1970, Table 1, p. 23, line 6 in factor outlay).

${ }^{8}$ NIP (1966), Table 1.13,

${ }^{9}$ Frane and Klein (1953), p. 336.

${ }^{10}$ Ando and Brown (1963).
} 
Personal income taxes on income from labor services, as estimated by Ando and Brown, are a remarkably stable proportion of total personal income tax receipts. The 1929-1958 figures show an average proportion of 0.755 with a negligible amount of variation. Statistics of Income $e^{11}$ indicates that the ratio of labor to property income was very stable in the 1951-1958 period and that

TABLE 5

Gross Private National Receipts and Expenditures, 1929-1969 (CURRent Prices)

\begin{tabular}{|c|c|c|c|}
\hline Year & $\begin{array}{c}\text { Gross } \\
\text { Private } \\
\text { National } \\
\text { Income }\end{array}$ & $\begin{array}{c}\text { Labor } \\
\text { Compensa- } \\
\text { tion }\end{array}$ & $\begin{array}{c}\text { Property } \\
\text { Compensa- } \\
\text { tion }\end{array}$ \\
\hline 1929 & 102.7 & 65.5 & 37.1 \\
\hline 1930 & 90.1 & 60.8 & 29.3 \\
\hline 1931 & 76.9 & 52.7 & 24.1 \\
\hline 1932 & 56.2 & 42.3 & 13.9 \\
\hline 1933 & 55.3 & 39.9 & 15.3 \\
\hline 1934 & 63.8 & 45.4 & 18.4 \\
\hline 1935 & 69.2 & 49.1 & 20.1 \\
\hline 1936 & 79.0 & 55.2 & 23.8 \\
\hline 1937 & 85.6 & 61.0 & 24.6 \\
\hline 1938 & 80.6 & 57.6 & 23.1 \\
\hline 1939 & 86.8 & 61.1 & 25.8 \\
\hline 1940 & 94.1 & 65.3 & 28.8 \\
\hline 1941 & 112.1 & 79.3 & 32.8 \\
\hline 1942 & 136.7 & 100.7 & 35.9 \\
\hline 1943 & 160.3 & 118.3 & 41.9 \\
\hline 1944 & 178.5 & 130.1 & 48.4 \\
\hline 1945 & 181.8 & 132.0 & 49.8 \\
\hline 1946 & 185.2 & 130.7 & 54.5 \\
\hline 1947 & 204.1 & 142.1 & 62.0 \\
\hline 1948 & 230.0 & 156.9 & 73.1 \\
\hline 1949 & 227.0 & 159.3 & 67.6 \\
\hline 1950 & 254.0 & 174.1 & 79.9 \\
\hline 1951 & 282.9 & 194.6 & 88.3 \\
\hline 1952 & 299.4 & 206.9 & 92.4 \\
\hline 1953 & 317.1 & 221.2 & 96.0 \\
\hline 1954 & 324.3 & 223.6 & 100.7 \\
\hline 1955 & 354.7 & 239.3 & 115.4 \\
\hline 1956 & 370.5 & 256.7 & 113.8 \\
\hline 1957 & 388.6 & 269.2 & 119.5 \\
\hline 1958 & 399.5 & 271.5 & 128.1 \\
\hline 1959 & 431.9 & 292.3 & 139.7 \\
\hline 1960 & 448.5 & 305.8 & 142.7 \\
\hline 1961 & 462.0 & 314.7 & 147.3 \\
\hline 1962 & 496.2 & 333.9 & 162.3 \\
\hline 1963 & 522.8 & 350.0 & 172.3 \\
\hline 1964 & 567.2 & 379.2 & 188.0 \\
\hline 1965 & 609.9 & 404.9 & 205.0 \\
\hline 1966 & 669.4 & 442.2 & 227.2 \\
\hline 1967 & 708.0 & 470.4 & 237.6 \\
\hline 1968 & 756.0 & 511.0 & 245.0 \\
\hline 1969 & 807.8 & 551.8 & 256.0 \\
\hline
\end{tabular}

${ }^{11}$ Statistics of Income: Individual Income Tax Returns, U.S. Treasury Dept., various years. 
TABLE 5-continued

\begin{tabular}{|c|c|c|c|c|}
\hline Year & $\begin{array}{c}\text { Gross } \\
\text { Private } \\
\text { National } \\
\text { Receipts } \\
\text { and Expen- } \\
\text { ditures }\end{array}$ & $\begin{array}{l}\text { Con- } \\
\text { sumption } \\
\text { Expen- } \\
\text { ditures }\end{array}$ & $\begin{array}{c}\text { Consumer } \\
\text { Outlays }\end{array}$ & $\begin{array}{c}\text { Gross } \\
\text { Private } \\
\text { National } \\
\text { Savings }\end{array}$ \\
\hline 1929 & 103.5 & 77.0 & 78.1 & 25.4 \\
\hline 1930 & 91.0 & 71.4 & 72.4 & 18.6 \\
\hline 1931 & 78.8 & 63.5 & 64.4 & 14.3 \\
\hline 1932 & 57.4 & 50.0 & 50.8 & 6.7 \\
\hline 1933 & 56.5 & 49.3 & 50.0 & 6.5 \\
\hline 1934 & 65.1 & 53.9 & 54.6 & 10.5 \\
\hline 1935 & 70.7 & 56.4 & 57.1 & 13.7 \\
\hline 1936 & 81.7 & 62.8 & 63.5 & 18.2 \\
\hline 1937 & 87.2 & 66.5 & 67.2 & 20.0 \\
\hline 1938 & 82.3 & 65.4 & 66.0 & 16.3 \\
\hline 1939 & 88.5 & 67.6 & 68.2 & 20.3 \\
\hline 1940 & 95.7 & 70.6 & 71.3 & 24.4 \\
\hline 1941 & 113.8 & 78.7 & 79.4 & 34.4 \\
\hline 1942 & 138.4 & 87.1 & 87.8 & 50.6 \\
\hline 1943 & 162.0 & 103.0 & 103.9 & 58.1 \\
\hline 1944 & 180.7 & 111.6 & 112.6 & 68.1 \\
\hline 1945 & 185.9 & 123.1 & 124.3 & 61.6 \\
\hline 1946 & 193.4 & 142.8 & 144.1 & 49.4 \\
\hline 1947 & 212.7 & 158.6 & 159.9 & 52.8 \\
\hline 1948 & 238.0 & 171.0 & 172.6 & 65.4 \\
\hline 1949 & 234.7 & 166.6 & 168.1 & 66.6 \\
\hline 1950 & 261.8 & 184.8 & 186.3 & 75.5 \\
\hline 1951 & 289.6 & 200.7 & 202.2 & 87.4 \\
\hline 1952 & 306.0 & 215.3 & 216.9 & 89.0 \\
\hline 1953 & 323.6 & 227.6 & 229.4 & 94.2 \\
\hline 1954 & 331.0 & 235.2 & 237.2 & 93.8 \\
\hline 1955 & 361.9 & 252.8 & 254.8 & 107.1 \\
\hline 1956 & 377.7 & 265.9 & 268.3 & 109.4 \\
\hline 1957 & 396.2 & 278.7 & 281.4 & 114.9 \\
\hline 1958 & 407.7 & 293.6 & 296.5 & 111.2 \\
\hline 1959 & 440.3 & 315.6 & 318.7 & 121.6 \\
\hline 1960 & 456.9 & 331.8 & 334.9 & 122.0 \\
\hline 1961 & 471.0 & 343.0 & 346.4 & 124.6 \\
\hline 1962 & 505.4 & 360.4 & 364.2 & 141.2 \\
\hline 1963 & 532.5 & 380.8 & 385.0 & 147.5 \\
\hline 1964 & 577.4 & 406.5 & 411.3 & 166.1 \\
\hline 1965 & 621.1 & 433.9 & 439.1 & 181.9 \\
\hline 1966 & 681.3 & 470.8 & 476.6 & 204.8 \\
\hline 1967 & 721.8 & 499.0 & 505.7 & 216.1 \\
\hline 1968 & 771.5 & 536.2 & 543.7 & 227.8 \\
\hline 1969 & 825.7 & 583.5 & 591.9 & 233.8 \\
\hline
\end{tabular}

pattern has continued to the present. We allocate a proportion of 0.755 of personal income taxes to labor income for all years from 1959 to 1969. Prior to 1959 we use the actual proportions estimated by Ando and Brown to allocate personal income taxes to labor income. The remainder of personal income taxes are attributed to property income.

We allocate federal estate and gift taxes, state and local death and gift taxes, motor vehicle licences, personal property taxes and other taxes to property 
income. We present the components of labor and property income for 1958 in Table 4. We present annual estimates of gross private national income, labor income, property income, consumer receipts and expenditures, consumption expenditures, consumer outlays, and gross private national saving in Table 5.

\section{Consumption Expenditures and Labor and Property Compensation}

\subsection{Introduction}

In the preceding section we have presented accounts for the income and expenditure of the U.S. private national economy in current prices. In this section we present accounts for consumption expenditures and for labor and property compensation in current prices. Consumption expenditures is a component of gross national product; methods for measurement of consumption expenditures in constant prices are well established. The quantity of labor compensation in constant prices can be interpreted as the quantity of labor services supplied to the U.S. private national economy. Similarly, the quantity of property compensation can be interpreted as the quantity of capital services supplied.

The value of labor and property compensation differs from the corresponding values of labor and property outlay by the value of tax payments on factor incomes. Quantity indexes of labor and property services supplied are weighted by prices that exclude tax payments on factor incomes; quantity indexes of labor and property services demanded are weighted by prices that include tax payments. To reflect these differences in concept we require a detailed allocation of taxes in income from both labor and capital. We allocate taxes on income by legal form of organization and by class of assets.

\subsection{Consumption Expenditures}

Our definition of consumption expenditures includes the portions of durable goods and services output assigned to personal consumption expenditures ${ }^{12}$ plus our imputations for consumer and institutional durables. The value of these expenditures from the consumer point of view includes retail taxes (customs duties, excise and sales taxes) and excludes subsidies. A detailed allocation of these items to various types of consumption would be desirable; we simply allocate these taxes proportionally to all components of output.

We construct a quantity index of consumption expenditures as a Divisia index of the quantity indexes of nondurables, services, ${ }^{13}$ and our estimate of imputed capital services. ${ }^{14}$ The price index is then computed as the ratio of consumption expenditures to the quantity index. We deflate consumer outlays by the price index of consumption expenditures. We present price and quantity indexes for consumption expenditures and consumer outlays in Table 6.

\subsection{Labor Compensation}

The consuming sector includes residents of the United States and armed forces overseas. Population data are avilable from the Economic Report of the

${ }^{12}$ NIP (1966), Table 1.4.

${ }^{13}$ NIP (1966), Table 1.2.

${ }^{14}$ Christensen and Jorgenson (1969), pp. 306-307. 
TABLE 6

Private National Consumption Expenditures and CONSUMER OUTLAYS, 1929-1969

(CONStant Prices of 1958)

\begin{tabular}{|c|c|c|c|}
\hline Year & $\begin{array}{c}\text { Consumption } \\
\text { Expenditures } \\
\text { and Consumer } \\
\text { Outlays, } \\
\text { Price Index }\end{array}$ & $\begin{array}{c}\text { Consumption } \\
\text { Expenditures, } \\
\text { Quantity } \\
\text { Index }\end{array}$ & $\begin{array}{c}\text { Consumer } \\
\text { Outlays, } \\
\text { Quantity } \\
\text { Index }\end{array}$ \\
\hline 1929 & 0.546 & 141.0 & 142.9 \\
\hline 1930 & 0.527 & 135.5 & 137.5 \\
\hline 1931 & 0.481 & 132.0 & 133.9 \\
\hline 1932 & 0.411 & 121.5 & 123.4 \\
\hline 1933 & 0.414 & 119.1 & 120.8 \\
\hline 1934 & 0.437 & 123.3 & 124.8 \\
\hline 1935 & 0.447 & 126.3 & 127.7 \\
\hline 1936 & 0.458 & 137.2 & 138.7 \\
\hline 1937 & 0.469 & 141.9 & 143.4 \\
\hline 1938 & 0.457 & 143.0 & 144.4 \\
\hline 1939 & 0.457 & 147.9 & 149.3 \\
\hline 1940 & 0.460 & 153.6 & 155.1 \\
\hline 1941 & 0.487 & 161.5 & 162.9 \\
\hline 1942 & 0.526 & 165.6 & 166.9 \\
\hline 1943 & 0.602 & 171.0 & 172.4 \\
\hline 1944 & 0.630 & 177.1 & 178.5 \\
\hline 1945 & 0.660 & 186.7 & 188.4 \\
\hline 1946 & 0.730 & 195.5 & 197.3 \\
\hline 1947 & 0.804 & 197.2 & 198.9 \\
\hline 1948 & 0.840 & 203.7 & 205.5 \\
\hline 1949 & 0.799 & 208.6 & 210.5 \\
\hline 1950 & 0.845 & 218.7 & 220.5 \\
\hline 1951 & 0.881 & 227.7 & 229.4 \\
\hline 1952 & 0.909 & 236.9 & 238.7 \\
\hline 1953 & 0.926 & 245.7 & 247.7 \\
\hline 1954 & 0.932 & 252.3 & 254.5 \\
\hline 1955 & 0.953 & 265.4 & 267.5 \\
\hline 1956 & 0.957 & 277.8 & 280.2 \\
\hline 1957 & 0.974 & 286.0 & 288.7 \\
\hline 1958 & 1.000 & 293.6 & 296.5 \\
\hline 1959 & 1.031 & 306.0 & 309.0 \\
\hline 1960 & 1.052 & 315.4 & 318.4 \\
\hline 1961 & 1.057 & 324.3 & 327.6 \\
\hline 1962 & 1.071 & 336.4 & 340.0 \\
\hline 1963 & 1.090 & 349.2 & 353.1 \\
\hline 1964 & 1.106 & 367.5 & 371.8 \\
\hline 1965 & 1.121 & 386.9 & 391.5 \\
\hline 1966 & 1.157 & 407.0 & 412.0 \\
\hline 1967 & 1.178 & 423.7 & 429.3 \\
\hline 1968 & 1.214 & 441.9 & 448.0 \\
\hline 1969 & 1.271 & 459.1 & 465.7 \\
\hline
\end{tabular}

President. ${ }^{15}$ We formulate measures of leisure, the quantity of labor services, and total time available. We assume that there is no economic decision involving the time of children thirteen years of age and younger. Our measure of the time available for the total population is the time endowment for the population

${ }^{15}$ Economic Report of the President (1972), U.S. Government Printing Office, Washington. 
fourteen years of age and older. The time endowment is twenty-four hours per day for the number of days in each year.

Labor services offered are not identified with hours actually worked. Unemployment is a measure of the number of persons willing to offer labor at the current wage rate who do not have a demand for their labor. We include a "normal workday" for the unemployed in working time. All non-working time is considered to be leisure. A case could be made for including even more in working time offered on the grounds that there is an interaction between labor force participation and unemployment rates. As unemployment is reduced, people previously discouraged from entering the labor force by high unemployment are induced to enter. ${ }^{16}$ We include in working time offered only the time of the unemployed, assuming that the average workweek is the same as for the employed.

Our data for manhours are from Kendrick. ${ }^{17}$ Kendrick provides total manhours for the farm sector, the general government sector, and the total private domestic sector. Hours for proprietors and unpaid family workers are included in his estimates. We provide our own hours estimate only for the rest of world sector. We assume that hours per man employed are equal to hours per man for the private domestic nonfarm economy. We adjust the total time endowment and the quantity of working time offered for quality change as measured by educational attainment. Both work and leisure are composed of quantities of labor services of varying qualities. Quantities of the different categories of labor services offered are combined into a Divisia quantity index of labor offered.

Our concept of labor compensation is net of personal income taxes. The effective tax rate on labor compensation is computed as the ratio of taxes on labor income to labor income including taxes. Price, quantity, and tax indexes for labor compensation are presented in Table 7.

\subsection{Property compensation}

The starting point for estimating price and quantity components of property compensation is a set of perpetual inventory estimates of stocks of each type of capital employed in measuring capital input in constant prices in the production account. ${ }^{18} \mathrm{We}$ assume that the flow of capital services from each type of tangible asset is proportional to the stock. Real property compensation for each asset is equal to the real service flow. Similarly real property compensation from the government and rest of world sectors is proportional to the quantity of net claims on governments and foreigners.

Prices of capital input from the point of view of the producer include both direct and indirect taxes. To obtain prices for capital input from the point of

${ }^{16}$ See Bowen and Finegan (1969) and the references given there.

${ }^{17}$ These data have been compiled for John W. Kendrick's study, Postwar Productivity Trends in the United States, for the National Bureau of Economic Research (1972). We are indebted to Kendrick for providing us with these data in advance of publication.

${ }^{18}$ The perpetual inventory method is discussed by Goldsmith (1951) and employed extensively in his Study of Saving (1955) and more recent studies of U.S. national wealth (1962, 1963, 1965). This method is used in the Bureau of Economic Analysis Capital Stock Study. See footnote 22 below. 
TABLE 7

NATIONAL LABOR COMPENSATION, 1929-1969

(Constant Prices of 1958)

\begin{tabular}{|c|c|c|c|}
\hline Year & $\begin{array}{l}\text { Price } \\
\text { Index }\end{array}$ & $\begin{array}{l}\text { Quantity } \\
\text { Index }\end{array}$ & $\begin{array}{l}\text { Effective } \\
\text { Tax Rate }\end{array}$ \\
\hline 1929 & 0.278 & 235.8 & 0.001 \\
\hline 1930 & 0.260 & 234.0 & 0.001 \\
\hline 1931 & 0.226 & 233.8 & 0.001 \\
\hline 1932 & 0.185 & 229.0 & 0.001 \\
\hline 1933 & 0.171 & 233.1 & 0.004 \\
\hline 1934 & 0.203 & 224.0 & 0.004 \\
\hline 1935 & 0.212 & 231.6 & 0.005 \\
\hline 1936 & 0.227 & 243.5 & 0.005 \\
\hline 1937 & 0.248 & 246.3 & 0.007 \\
\hline 1938 & 0.237 & 242.7 & 0.009 \\
\hline 1939 & 0.246 & 248.1 & 0.008 \\
\hline 1940 & 0.261 & 250.5 & 0.009 \\
\hline 1941 & 0.304 & 260.8 & 0.011 \\
\hline 1942 & 0.367 & 274.6 & 0.024 \\
\hline 1943 & 0.392 & 301.7 & 0.086 \\
\hline 1944 & 0.424 & 306.8 & 0.086 \\
\hline 1945 & 0.456 & 289.3 & 0.090 \\
\hline 1946 & 0.505 & 259.2 & 0.081 \\
\hline 1947 & 0.553 & 257.1 & 0.092 \\
\hline 1948 & 0.606 & 258.9 & 0.081 \\
\hline 1949 & 0.620 & 256.9 & 0.068 \\
\hline 1950 & 0.670 & 260.0 & 0.065 \\
\hline 1951 & 0.723 & 269.1 & 0.092 \\
\hline 1952 & 0.759 & 272.7 & 0.103 \\
\hline 1953 & 0.811 & 272.7 & 0.101 \\
\hline 1954 & 0.831 & 269.0 & 0.089 \\
\hline 1955 & 0.874 & 273.7 & 0.090 \\
\hline 1956 & 0.928 & 276.7 & 0.094 \\
\hline 1957 & 0.981 & 274.3 & 0.095 \\
\hline 1958 & 1.000 & 271.5 & 0.094 \\
\hline 1959 & 1.059 & 275.9 & 0.095 \\
\hline 1960 & 1.093 & 279.7 & 0.099 \\
\hline 1961 & 1.123 & 280.2 & 0.098 \\
\hline 1962 & 1.180 & 283.0 & 0.101 \\
\hline 1963 & 1.224 & 286.0 & 0.102 \\
\hline 1964 & 1.306 & 290.4 & 0.090 \\
\hline 1965 & 1.360 & 297.7 & 0.094 \\
\hline 1966 & 1.441 & 306.8 & 0.099 \\
\hline 1967 & 1.496 & 314.4 & 0.102 \\
\hline 1968 & 1.591 & 321.2 & 0.111 \\
\hline 1969 & 1.678 & 328.8 & 0.123 \\
\hline
\end{tabular}

view of the owner of the asset we exclude all taxes. Excluding both direct and indirect taxes, the price of capital services becomes:

$$
q_{K, t}=q_{A, t-1} r_{t}+q_{A, t} \delta-\left(q_{A, t}-q_{A, t-1}\right),
$$

where $r_{t}$ is the after-tax rate of return. The depreciation rate $\delta$ is different from zero only for structures (0.056), equipment (0.138), and consumer durables $(0.200)$ employed in the private domestic sector. For inventories, land, and financial claims on the government and rest of world sectors the capital service 
price reduces to the cost of capital $q_{A, t-1} r_{t}$ less revaluation of assets $q_{A, t}-q_{A, t-1}$. For a financial asset the value of capital services is equal to earnings on the asset, for example, interest payments on a bond.

To construct price and quantity indexes of property compensation for the income and expenditure account our procedure is analogous to the methods we have used for the production account, except for the treatment of taxes. Property compensation before taxes includes the property share of gross private domestic factor outlay, corporate profits and net interest originating in the foreign sector, net interest paid by government, and investment income of social insurance funds net of transfers to general government. We have described effective rates of business property taxation and corporate income taxation in our presentation of the production account. ${ }^{19}$ We now compute an effective rate of personal

\section{TABLE 8}

Gross Private National Property Compensation by Sector of Origin, 1958

\begin{tabular}{lr}
\hline & \multicolumn{2}{c}{ Corporate Property Compensation } \\
1. $\quad$ Gross private domestic outlay for corporate capital services (our imputation) & 67.9 \\
2. - Corporate profits tax liability (Table 6.14) & 19.0 \\
3. - Corporate business property taxes (our imputation) & 6.7 \\
4. - Personal income taxes attributed to corporate property income (our imputation) & 3.6 \\
$5 . \quad$ - Wealth taxes attributed to corporate assets (our imputation) & 0.5 \\
$6 . \quad$ - Corporate property compensation & 38.1
\end{tabular}

\section{Noncorporate Property Compensation}

1. Gross private domestic outlay for noncorporate capital services (our imputation)

2. - Noncorporate business property taxes (our imputation)

3. - Personal income taxes attributed to noncorporate property income (our imputation)

4. - Wealth taxes attributed to noncorporate assets (our imputation)

5. = Noncorporate property compensation

\section{Household and Institutional Property Compensation}

1. Gross private domestic outlay for household and institutional capital services (our imputation)

2. - Property taxes, owner-occupied dwellings (Table 7.3)

3. - Personal property taxes, consumer durables (Table 3.3)

4. - Wealth taxes attributed to household assets (our imputation)

5. = Household and institutional property compensation

\section{Compensation from Net Claims on Government and Rest of World}

1. Net interest paid by government (Tables 3.1 and 3.3)

2. + Investment income of social insurance funds less transfers to general government (Table 3.7)

3. + Corporate profits, rest of world (Table 1.13)

4. + Net interest, rest of world (Table 1.13)

5. - Personal income taxes attributed to compensation from net claims (our imputation)

6. Wealth taxes attributed to net claims (our imputation)

7. $=$ Compensation from net claims

${ }^{a}$ All table references are to The National Income and Product Accounts of the United States, 1929-65, Statistical Tables, A Supplement to the Survey of Current Business, August 1966.

${ }^{10}$ Christensen and Jorgenson (1970). 
income taxation on property compensation net of business property taxes and the corporate income tax, and an effective rate of estate, death, and gift taxation on wealth.

We allocate federal estate and gift taxes and state and local death and gift taxes proportionally to all the components of private national wealth. ${ }^{20}$ Property

TABLE 9

Gross Private Natronal Property Compensation by Sector, 1929-1969 (Current Prices)

\begin{tabular}{|c|c|c|c|c|}
\hline Year & $\begin{array}{l}\text { Corporate } \\
\text { Sector }\end{array}$ & $\begin{array}{l}\text { Non-corporate } \\
\text { Sector }\end{array}$ & $\begin{array}{l}\text { Households } \\
\text { and } \\
\text { Institutions }\end{array}$ & $\begin{array}{c}\text { Net Claims } \\
\text { on Governments } \\
\text { and } \\
\text { Rest of World }\end{array}$ \\
\hline 1929 & 14.348 & 7.871 & 13.227 & 1.681 \\
\hline 1930 & 11.598 & 3.570 & 12.558 & 1.547 \\
\hline 1931 & 7.766 & 2.874 & 12.011 & 1.492 \\
\hline 1932 & 4.542 & 0.051 & 8.066 & 1.235 \\
\hline 1933 & 3.895 & 0.643 & 9.566 & 1.213 \\
\hline 1934 & 6.368 & 1.444 & 9.171 & 1.413 \\
\hline 1935 & 7.625 & 2.885 & 8.160 & 1.406 \\
\hline 1936 & 9.085 & 4.009 & 9.481 & 1.258 \\
\hline 1937 & 9.795 & 4.051 & 9.428 & 1.311 \\
\hline 1938 & 8.311 & 3.638 & 9.801 & 1.324 \\
\hline 1939 & 9.559 & 4.713 & 10.124 & 1.370 \\
\hline 1940 & 11.371 & 5.531 & 10.321 & 1.545 \\
\hline 1941 & 12.312 & 8.265 & 10.722 & 1.519 \\
\hline 1942 & 13.971 & 11.281 & 8.965 & 1.715 \\
\hline 1943 & 14.121 & 11.714 & 14.144 & 1.955 \\
\hline 1944 & 15.519 & 15.749 & 14.388 & 2.738 \\
\hline 1945 & 13.486 & 16.907 & 16.042 & 3.342 \\
\hline 1946 & 13.015 & 17.345 & 19.866 & 4.221 \\
\hline 1947 & 17.852 & 16.174 & 23.321 & 4.657 \\
\hline 1948 & 24.368 & 17.914 & 25.660 & 5.113 \\
\hline 1949 & 25.193 & 16.384 & 20.683 & 5.373 \\
\hline 1950 & 24.628 & 18.363 & 31.570 & 5.321 \\
\hline 1951 & 26.396 & 23.611 & 32.645 & 5.643 \\
\hline 1952 & 27.371 & 21.375 & 37.995 & 5.645 \\
\hline 1953 & 27.745 & 19.920 & 42.531 & 5.736 \\
\hline 1954 & 30.020 & 19.682 & 44.606 & 6.345 \\
\hline 1955 & 36.287 & 20.282 & 52.297 & 6.502 \\
\hline 1956 & 35.955 & 17.818 & 53.292 & 6.721 \\
\hline 1957 & 38.024 & 19.690 & 54.421 & 7.295 \\
\hline 1958 & 38.104 & 23.507 & 59.222 & 7.216 \\
\hline 1959 & 43.359 & 20.619 & 67.732 & 7.963 \\
\hline 1960 & 43.034 & 19.276 & 71.965 & 8.369 \\
\hline 1961 & 44.600 & 21.013 & 73.086 & 8.591 \\
\hline 1962 & 51.516 & 23.729 & 77.429 & 9.633 \\
\hline 1963 & 54.333 & 24.033 & 84.222 & 10.202 \\
\hline 1964 & 61.069 & 24.645 & 90.617 & 11.651 \\
\hline 1965 & 69.903 & 27.774 & 95.100 & 12.201 \\
\hline 1966 & 76.634 & 32.594 & 105.157 & 12.755 \\
\hline 1967 & 77.569 & 34.347 & 111.899 & 13.748 \\
\hline 1968 & 79.543 & 32.595 & 117.930 & 14.845 \\
\hline 1969 & 79.261 & 30.532 & 131.679 & 14.457 \\
\hline
\end{tabular}

${ }^{20}$ NIP (1966), Tables 3,1 and 3.3. 
income from assets in the household sector is not subject to personal income taxation; thus we must allocate personal income taxes attributed to property compensation among the corporate, noncorporate, government, and foreign sectors. A detailed allocation of personal income taxes to the various types of property compensation would be desirable; we simply allocate the taxes

TABLE 10

Gross Private National Property Compensation, Rates of Return on Capital, 1929-1969

a. Nominal rates of return

\begin{tabular}{|c|c|c|c|c|c|}
\hline Year & $\begin{array}{l}\text { Corporate } \\
\text { Sector }\end{array}$ & $\begin{array}{c}\text { Non- } \\
\text { Corporate } \\
\text { Sector }\end{array}$ & $\begin{array}{l}\text { Households } \\
\text { and Insti- } \\
\text { tutions }\end{array}$ & $\begin{array}{l}\text { Net Claims } \\
\text { on Govern- } \\
\text { ments and } \\
\text { Rest of World }\end{array}$ & $\begin{array}{c}\text { Private } \\
\text { National } \\
\text { Economy }\end{array}$ \\
\hline 1929 & 0.076 & 0.056 & 0.029 & 0.078 & 0.053 \\
\hline 1930 & -0.008 & -0.067 & -0.031 & 0.042 & -0.028 \\
\hline 1931 & -0.065 & -0.117 & -0.092 & -0.017 & -0.084 \\
\hline 1932 & -0.091 & -0.141 & -0.151 & 0.036 & -0.113 \\
\hline 1933 & -0.005 & 0.010 & 0.017 & 0.043 & 0.012 \\
\hline 1934 & 0.082 & 0.062 & 0.090 & 0.108 & 0.083 \\
\hline 1935 & 0.062 & 0.049 & 0.002 & 0.032 & 0.034 \\
\hline 1936 & 0.078 & 0.071 & 0.059 & 0.009 & 0.060 \\
\hline 1937 & 0.131 & 0.073 & 0.078 & 0.034 & 0.084 \\
\hline 1938 & 0.029 & -0.005 & 0.032 & -0.001 & 0.017 \\
\hline 1939 & 0.052 & 0.027 & 0.019 & 0.007 & 0.027 \\
\hline 1940 & 0.096 & 0.070 & 0.041 & 0.002 & 0.056 \\
\hline 1941 & 0.154 & 0.159 & 0.092 & 0.088 & 0.123 \\
\hline 1942 & 0.181 & 0.187 & 0.079 & 0.109 & 0.136 \\
\hline 1943 & 0.129 & 0.156 & 0.096 & 0.010 & 0.098 \\
\hline 1944 & 0.124 & 0.172 & 0.103 & -0.025 & 0.087 \\
\hline 1945 & 0.077 & 0.170 & 0.080 & -0.017 & 0.066 \\
\hline 1946 & 0.158 & 0.265 & 0.125 & 0.027 & 0.123 \\
\hline 1947 & 0.243 & 0.253 & 0.186 & 0.008 & 0.154 \\
\hline 1948 & 0.140 & 0.141 & 0.114 & 0.018 & 0.099 \\
\hline 1949 & 0.055 & 0.036 & -0.021 & 0.024 & 0.020 \\
\hline 1950 & 0.096 & 0.152 & 0.074 & 0.042 & 0.087 \\
\hline 1951 & 0.136 & 0.161 & 0.085 & 0.028 & 0.100 \\
\hline 1952 & 0.062 & 0.065 & 0.040 & 0.024 & 0.047 \\
\hline 1953 & 0.048 & 0.048 & 0.027 & 0.034 & 0.038 \\
\hline 1954 & 0.048 & 0.067 & 0.017 & 0.030 & 0.037 \\
\hline 1955 & 0.076 & 0.073 & 0.055 & 0.029 & 0.058 \\
\hline 1956 & 0.103 & 0.092 & 0.071 & 0.034 & 0.076 \\
\hline 1957 & 0.086 & 0.096 & 0,054 & 0.032 & 0.066 \\
\hline 1958 & 0.049 & 0.097 & 0.037 & 0.037 & 0.051 \\
\hline 1959 & 0.065 & 0.064 & 0.064 & 0.041 & 0.060 \\
\hline 1960 & 0.050 & 0.069 & 0.051 & 0.042 & 0.053 \\
\hline 1961 & 0.050 & 0.076 & 0.046 & 0.031 & 0.050 \\
\hline 1962 & 0.068 & 0.082 & 0.056 & 0.040 & 0.061 \\
\hline 1963 & 0.067 & 0.073 & 0.061 & 0.034 & 0.060 \\
\hline 1964 & 0.080 & 0.075 & 0.069 & 0.030 & 0.067 \\
\hline 1965 & 0.094 & 0.092 & 0.050 & 0.039 & 0.072 \\
\hline 1966 & 0.104 & 0.100 & 0.069 & 0.035 & 0.079 \\
\hline 1967 & 0.095 & 0.094 & 0.085 & 0.023 & 0.080 \\
\hline 1968 & 0.089 & 0.092 & 0.088 & 0.034 & 0.081 \\
\hline 1969 & 0.087 & 0.087 & 0.093 & 0.041 & 0.082 \\
\hline
\end{tabular}


TABLE 10-continued

b. Own rates of return

\begin{tabular}{|c|c|c|c|c|c|}
\hline Year & $\begin{array}{l}\text { Corporate } \\
\text { sector }\end{array}$ & $\begin{array}{l}\text { Non- } \\
\text { Corporate } \\
\text { Sector }\end{array}$ & $\begin{array}{l}\text { Households } \\
\text { and Institu- } \\
\text { tions }\end{array}$ & $\begin{array}{l}\text { Net claims } \\
\text { on Govern- } \\
\text { ments and } \\
\text { Rest of World }\end{array}$ & $\begin{array}{c}\text { Private } \\
\text { National } \\
\text { Economy }\end{array}$ \\
\hline 1929 & 0.074 & 0.058 & 0.012 & 0.052 & 0.044 \\
\hline 1930 & 0.050 & 0.016 & 0.008 & 0.047 & 0.025 \\
\hline 1931 & 0.022 & 0.010 & 0.014 & 0.044 & 0.018 \\
\hline 1932 & -0.002 & -0.019 & -0.001 & 0.035 & -0.002 \\
\hline 1933 & -0.004 & -0.012 & 0.019 & 0.033 & 0.007 \\
\hline 1934 & 0.026 & -0.002 & 0.015 & 0.036 & 0.017 \\
\hline 1935 & 0.042 & 0.017 & 0.009 & 0.031 & 0.023 \\
\hline 1936 & 0.060 & 0.031 & 0.020 & 0.027 & 0.034 \\
\hline 1937 & 0.063 & 0.027 & 0.013 & 0.026 & 0.031 \\
\hline 1938 & 0.040 & 0.020 & 0.011 & 0.026 & 0.023 \\
\hline 1939 & 0.056 & 0.033 & 0.015 & 0.025 & 0.032 \\
\hline 1940 & 0.075 & 0.042 & 0.014 & 0.027 & 0.038 \\
\hline 1941 & 0.076 & 0.069 & 0.008 & 0.025 & 0.043 \\
\hline 1942 & 0.074 & 0.089 & -0.020 & 0.024 & 0.037 \\
\hline 1943 & 0.067 & 0.085 & 0.011 & 0.018 & 0.042 \\
\hline 1944 & 0.075 & 0.115 & 0.008 & 0.018 & 0.048 \\
\hline 1945 & 0.057 & 0.119 & 0.016 & 0.016 & 0.045 \\
\hline 1946 & 0.046 & 0.115 & 0.037 & 0.018 & 0.046 \\
\hline 1947 & 0.057 & 0.086 & 0.034 & 0.019 & 0.044 \\
\hline 1948 & 0.070 & 0.079 & 0.025 & 0.021 & 0.045 \\
\hline 1949 & 0.060 & 0.061 & -0.003 & 0.023 & 0.032 \\
\hline 1950 & 0.054 & 0.068 & 0.025 & 0.022 & 0.040 \\
\hline 1951 & 0.049 & 0.081 & 0.010 & 0.024 & 0.037 \\
\hline 1952 & 0.042 & 0.062 & 0.017 & 0.024 & 0.034 \\
\hline 1953 & 0.037 & 0.054 & 0.024 & 0.023 & 0.033 \\
\hline 1954 & 0.040 & 0.051 & 0.024 & 0.025 & 0.033 \\
\hline 1955 & 0.056 & 0.051 & 0.036 & 0.024 & 0.042 \\
\hline 1956 & 0.045 & 0.036 & 0.026 & 0.025 & 0.033 \\
\hline 1957 & 0.040 & 0.039 & 0.019 & 0.027 & 0.030 \\
\hline 1958 & 0.034 & 0.048 & 0.022 & 0.026 & 0.031 \\
\hline 1959 & 0.043 & 0.035 & 0.033 & 0.027 & 0.035 \\
\hline 1960 & 0.039 & 0.029 & 0.034 & 0.028 & 0.033 \\
\hline 1961 & 0.039 & 0.033 & 0.032 & 0.028 & 0.033 \\
\hline 1962 & 0.050 & 0.038 & 0.035 & 0.030 & 0.039 \\
\hline 1963 & 0.051 & 0.036 & 0.039 & 0.031 & 0.040 \\
\hline 1964 & 0.059 & 0.035 & 0.041 & 0.035 & 0.044 \\
\hline 1965 & 0.068 & 0.039 & 0.040 & 0.035 & 0.047 \\
\hline 1966 & 0.070 & 0.046 & 0.045 & 0.036 & 0.050 \\
\hline 1967 & 0.058 & 0.044 & 0.043 & 0.037 & 0.047 \\
\hline 1968 & 0.052 & 0.036 & 0.039 & 0.038 & 0.042 \\
\hline 1969 & 0.042 & 0.027 & 0.042 & 0.036 & 0.038 \\
\hline
\end{tabular}

proportionately to all non-household property compensation after corporate and property taxes. The effective rate of personal income taxation on property compensation is computed as the ratio of personal income taxes to non-household property compensation before personal taxation. A detailed breakdown of property compensation by sector for 1958 , including the allocation of taxes, is presented in Table 8 ; property compensation by sector annually is presented in Table 9. 
The after tax return to capital in each sector includes property compensation, net of all taxes; it also includes capital gains and excludes economic depreciation. Our estimates of capital gains and economic depreciation for corporate and noncorporate tangible assets are discussed in detail in Christensen and Jorgenson. ${ }^{21}$ Depreciation is zero for the financial assets, which constitute net

TABLE 11

Gross Private National Property Compensation, 1929-1969 (Constant Prices of 1958)

\begin{tabular}{|c|c|c|c|c|c|}
\hline Year & $\begin{array}{c}\text { Corporate, } \\
\text { Price } \\
\text { Index }\end{array}$ & $\begin{array}{c}\text { Corporate, } \\
\text { Quantity } \\
\text { Index }\end{array}$ & $\begin{array}{c}\text { Non- } \\
\text { Corporate, } \\
\text { Price } \\
\text { Index }\end{array}$ & $\begin{array}{c}\text { Non- } \\
\text { Corporate, } \\
\text { Quantity } \\
\text { Index }\end{array}$ & $\begin{array}{c}\text { Households } \\
\text { and } \\
\text { Institutions, } \\
\text { Price Index }\end{array}$ \\
\hline 1929 & 0.056 & 257.9 & 0.039 & 200.9 & 0.048 \\
\hline 1930 & 0.044 & 264.0 & 0.017 & 212.2 & 0.045 \\
\hline 1931 & 0.029 & 263.4 & 0.013 & 216.0 & 0.044 \\
\hline 1932 & 0.018 & 255.5 & 0.000 & 214.9 & 0.031 \\
\hline 1933 & 0.016 & 237.2 & 0.003 & 208.6 & 0.039 \\
\hline 1934 & 0.029 & 221.5 & 0.007 & 202.6 & 0.039 \\
\hline 1935 & 0.036 & 213.8 & 0.015 & 197.6 & 0.036 \\
\hline 1936 & 0.043 & 209.5 & 0.020 & 197.5 & 0.042 \\
\hline 1937 & 0.046 & 211.6 & 0.020 & 201.8 & 01041 \\
\hline 1938 & 0.038 & 216.9 & 0.017 & 211.4 & 0.041 \\
\hline 1939 & 0.045 & 212.8 & 0.022 & 211.3 & 0.043 \\
\hline 1940 & 0.053 & 212.8 & 0.026 & 213.4 & 0.043 \\
\hline 1941 & 0.056 & 219.2 & 0.038 & 216.7 & 0.043 \\
\hline 1942 & 0.060 & 230.9 & 0.051 & 221.9 & 0.034 \\
\hline 1943 & 0.061 & 229.7 & 0.053 & 219.5 & 0.055 \\
\hline 1944 & 0.069 & 225.0 & 0.073 & 215.3 & 0.059 \\
\hline 1945 & 0.061 & 222.2 & 0.079 & 214.2 & 0.069 \\
\hline 1946 & 0.057 & 227.0 & 0.081 & 214.8 & 0.088 \\
\hline 1947 & 0.073 & 245.2 & 0.073 & 220.6 & 0.093 \\
\hline 1948 & 0.092 & 266.1 & 0.079 & 227.3 & 0.092 \\
\hline 1949 & 0.089 & 282.8 & 0.069 & 238.6 & 0.067 \\
\hline 1950 & 0.085 & 290.6 & 0.074 & 248.0 & 0.094 \\
\hline 1951 & 0.086 & 306.0 & 0.090 & 261.4 & 0.086 \\
\hline 1952 & 0.084 & 326.0 & 0.079 & 270.6 & 0.094 \\
\hline 1953 & 0.082 & 339.8 & 0.072 & 276.1 & 0.100 \\
\hline 1954 & 0.085 & 353.3 & 0.070 & 281.4 & 0.099 \\
\hline 1955 & 0.100 & 363.1 & 0.071 & 286.2 & 0.110 \\
\hline 1956 & 0.095 & 380.4 & 0.061 & 293.6 & 0.104 \\
\hline 1957 & 0.095 & 401.0 & 0.066 & 297.9 & 0.101 \\
\hline 1958 & 0.091 & 418.1 & 0.078 & 302.0 & 0.105 \\
\hline 1959 & 0.102 & 424.7 & 0.068 & 305.0 & 0.118 \\
\hline 1960 & 0.098 & 438.1 & 0.062 & 310.3 & 0.120 \\
\hline 1961 & 0.098 & 454.3 & 0.067 & 315.7 & 0.117 \\
\hline 1962 & 0.111 & 465.2 & 0.074 & 319.9 & 0.121 \\
\hline 1963 & 0.113 & 482.2 & 0.073 & 328.1 & 0.128 \\
\hline 1964 & 0.122 & 500.6 & 0.073 & 337.4 & 0.130 \\
\hline 1965 & 0.133 & 525.0 & 0.080 & 347.8 & 0.129 \\
\hline 1966 & 0.138 & 556.8 & 0.090 & 361.5 & 0.134 \\
\hline 1967 & 0.129 & 599.7 & 0.092 & 374.3 & 0.134 \\
\hline 1968 & 0.125 & 634.3 & 0.084 & 386.3 & 0.135 \\
\hline 1969 & 0.119 & 667.8 & 0.076 & 400.9 & 0.143 \\
\hline
\end{tabular}

${ }^{21}$ Christensen and Jorgenson (1969). 
TABLE 11-continued

\begin{tabular}{|c|c|c|c|c|c|}
\hline Year & $\begin{array}{l}\text { Households } \\
\text { and } \\
\text { Institutions, } \\
\text { Quantity } \\
\text { Index }\end{array}$ & $\begin{array}{l}\text { Government } \\
\text { and } \\
\text { Rest of World, } \\
\text { Price Index }\end{array}$ & $\begin{array}{l}\text { Government } \\
\text { and } \\
\text { Rest of World, } \\
\text { Quantity } \\
\text { Index }\end{array}$ & $\begin{array}{c}\text { Private } \\
\text { National, } \\
\text { Price Index }\end{array}$ & $\begin{array}{c}\text { Private } \\
\text { National, } \\
\text { Quantity } \\
\text { Index }\end{array}$ \\
\hline 1929 & 273.9 & 0.048 & 35.1 & 0.045 & 834.0 \\
\hline 1930 & 278.2 & 0.044 & 35.0 & 0.034 & 854.7 \\
\hline 1931 & 272.8 & 0.041 & 36.3 & 0.028 & 849.8 \\
\hline 1932 & 263.0 & 0.031 & 40.0 & 0.017 & 830.7 \\
\hline 1933 & 246.3 & 0.029 & 42.3 & 0.020 & 784.7 \\
\hline 1934 & 232.5 & 0.032 & 44.2 & 0.025 & 745.3 \\
\hline 1935 & 224.4 & 0.030 & 47.3 & 0.028 & 725.8 \\
\hline 1936 & 223.6 & 0.025 & 49.5 & 0.033 & 721.3 \\
\hline 1937 & 230.6 & 0.025 & 53.2 & 0.033 & 738.2 \\
\hline 1938 & 237.5 & 0.024 & 54.6 & 0.030 & 760.9 \\
\hline 1939 & 235.5 & 0.023 & 59.0 & 0.034 & 756.2 \\
\hline 1940 & 240.5 & 0.024 & 63.8 & 0.038 & 766.8 \\
\hline 1941 & 250.2 & 0.022 & 67.8 & 0.041 & 791.3 \\
\hline 1942 & 263.4 & 0.023 & 75.1 & 0.043 & 828.7 \\
\hline 1943 & 255.3 & 0.018 & 108.4 & 0.050 & 831.1 \\
\hline 1944 & 243.9 & 0.018 & 153.7 & 0.059 & 823.6 \\
\hline 1945 & 232.4 & 0.016 & 209.8 & 0.061 & 822.7 \\
\hline 1946 & 225.4 & 0.017 & 255.8 & 0.066 & 831.1 \\
\hline 1947 & 249.7 & 0.018 & 259.0 & 0.070 & 888.5 \\
\hline 1948 & 279.5 & 0.020 & 257.2 & 0.075 & 956.5 \\
\hline 1949 & 307.9 & 0.021 & 253.7 & 0.066 & 1019.7 \\
\hline 1950 & 337.0 & 0.020 & 260.5 & 0.074 & 1074.0 \\
\hline 1951 & 379.7 & 0.022 & 250.9 & 0.077 & 1154.3 \\
\hline 1952 & 404.9 & 0.023 & 249.2 & 0.076 & 1216.0 \\
\hline 1953 & 423.7 & 0.022 & 257.3 & 0.076 & 1262.9 \\
\hline 1954 & 450.2 & 0.024 & 265.9 & 0.076 & 1320.0 \\
\hline 1955 & 474.3 & 0.024 & 275.5 & 0.084 & 1369.8 \\
\hline 1956 & 513.2 & 0.024 & 275.5 & 0.079 & 1447.5 \\
\hline 1957 & 539.5 & 0.026 & 276.0 & 0.079 & 1510.0 \\
\hline 1958 & 562.0 & 0.026 & 282.3 & 0.082 & 1564.2 \\
\hline 1959 & 574.0 & 0.027 & 294.7 & 0.088 & 1594.1 \\
\hline 1960 & 599.3 & 0.028 & 296.6 & 0.087 & 1648.7 \\
\hline 1961 & 622.3 & 0.029 & 298.4 & 0.086 & 1703.1 \\
\hline 1962 & 639.4 & 0.031 & 307.0 & 0.093 & 1744.9 \\
\hline 1963 & 666.5 & 0.032 & 315.3 & 0.095 & 1809.8 \\
\hline 1964 & 699.5 & 0.036 & 321.4 & 0.100 & 1884.3 \\
\hline 1965 & 737.9 & 0.037 & 333.8 & 0.104 & 1975.9 \\
\hline 1966 & 785.4 & 0.037 & 340.9 & 0.109 & 2088.5 \\
\hline 1967 & 832.8 & 0.039 & 353.0 & 0.107 & 2215.5 \\
\hline 1968 & 872.6 & 0.039 & 378.6 & 0.105 & 2326.9 \\
\hline 1969 & 923.3 & 0.037 & 395.4 & 0.104 & 2450.2 \\
\hline
\end{tabular}

claims on governments and foreigners. Capital gains on net claims on foreigners are computed as the yearly increase in net claims less net private foreign investment. Capital gains on net claims on governments are computed as the yearly increase in net claims on governments less the current government deficit. These items are discussed in greater detail below.

The after tax rate of return in each sector is computed by dividing the after tax return to capital by the value of assets. These rates of return are nominal 
or money rates. We also compute the real or own rates of return by excluding capital gains from the return to capital. Nominal and own rates of return for each sector and for the private national economy are presented in Table 10.

We have determined the after tax rates of return and we can now estimate the price of capital services for each asset from the formula above as a function of the rate of return, the depreciation rate, and the current and lagged acquisition price. The after tax property compensation of each asset in each sector is the product of the capital service price and the quantity of capital. Real property income for each sector and the private national economy is obtained as a Divisia quantity index of real property income from each asset. The price indexes for property income are computed as the ratios of property income to the quantity indexes. The price and quantity indexes for property income for each sector are presented in Table 11 .

\section{Accumulation and Revaluation}

\subsection{Introduction}

The fundamental accounting identity for the accumulation account is that gross private national saving, taken from the income and expenditure account, is equal to gross private national capital formation. Gross private national saving may be expressed as the sum of depreciation and net private national

TABLE 12

Gross Private National Capital formation, Saving, and Revaluation, 1958 (Current Prices)

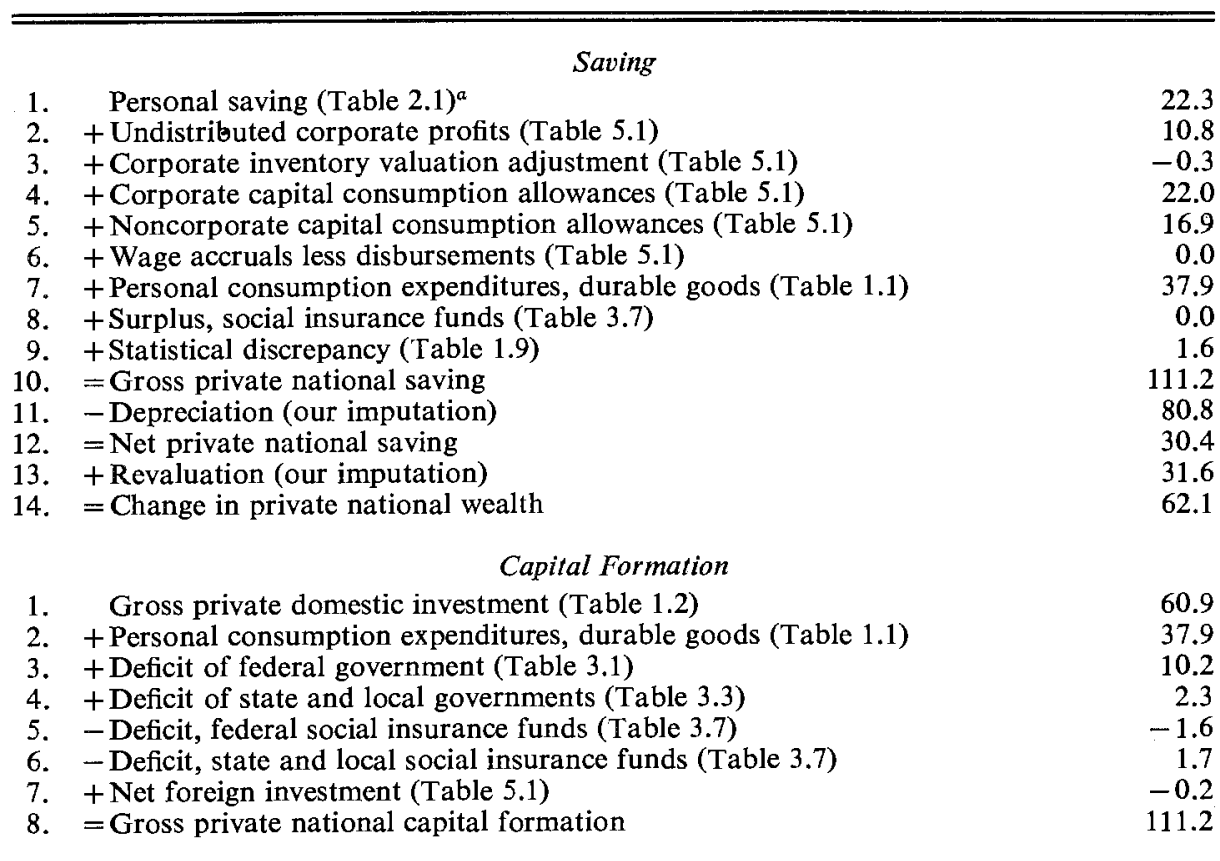

${ }^{a}$ All table references are to The National Income and Product Accounts of the United States, 1929-65, Statistical Tables, A Supplement to the Survey of Current Business, August 1966. 
saving. Net private national saving is equal to the change in wealth from period to period less revaluation of assets. Gross private national capital formation can be expressed as the sum of replacement and net private national capital formation. We present data in constant prices for saving and capital formation, both gross and net, and for depreciation, replacement, and revaluation.

TABLE 13

Gross Private National Capital Formation, Saving, and Revaluation, 1929-1969 (CURRENT Prices)

\begin{tabular}{|c|c|c|c|c|c|}
\hline Year & $\begin{array}{c}\text { Gross } \\
\text { Private } \\
\text { National } \\
\text { Saving and } \\
\text { Capital } \\
\text { Formation }\end{array}$ & $\begin{array}{l}\text { Replacement } \\
\text { and } \\
\text { Depreciation }\end{array}$ & $\begin{array}{c}\text { Net } \\
\text { Private } \\
\text { National } \\
\text { Saving and } \\
\text { Capital } \\
\text { Formation }\end{array}$ & Revaluation & $\begin{array}{c}\text { Change } \\
\text { in } \\
\text { Wealth }\end{array}$ \\
\hline 1929 & 25.4 & 19.2 & 6.2 & 3.5 & 9.7 \\
\hline 1930 & 18.6 & 19.0 & -0.4 & -22.0 & -22.4 \\
\hline 1931 & 14.3 & 17.2 & -2.8 & -39.9 & -42.7 \\
\hline 1932 & 6.7 & 14.7 & -8.0 & -38.7 & -46.7 \\
\hline 1933 & 6.5 & 13.3 & -6.7 & 1.7 & -5.0 \\
\hline 1934 & 10.5 & 13.5 & -2.9 & 19.8 & 18.9 \\
\hline 1935 & 13.7 & 12.9 & 0.7 & 3.4 & 4.2 \\
\hline 1936 & 18.2 & 12.9 & 5.3 & 8.0 & 13.3 \\
\hline 1937 & 20.0 & 14.1 & 5.9 & 17.4 & 23.2 \\
\hline 1938 & 16.3 & 14.8 & 1.4 & -2.1 & -0.7 \\
\hline 1939 & 20.3 & 14.5 & 5.8 & -1.5 & 4.3 \\
\hline 1940 & 24.4 & 15.0 & 9.4 & 6.2 & 15.7 \\
\hline 1941 & 34.4 & 16.8 & 17.6 & 30.2 & 47.8 \\
\hline 1942 & 50.6 & 20.3 & 30.3 & 41.7 & 72.0 \\
\hline 1943 & 58.1 & 20.9 & 37.2 & 27.6 & 64.7 \\
\hline 1944 & 68.1 & 21.7 & 46.5 & 21.8 & 68.3 \\
\hline 1945 & 61.6 & 21.7 & 39.9 & 13.1 & 53.0 \\
\hline 1946 & 49.4 & 22.9 & 26.4 & 52.3 & 78.8 \\
\hline 1947 & 52.8 & 28.4 & 24.4 & 83.4 & 107.8 \\
\hline 1948 & 65.4 & 33.9 & 31.5 & 46.7 & 78.2 \\
\hline 1949 & 66.6 & 37.9 & 28.8 & -11.1 & 17.6 \\
\hline 1950 & 75.5 & 41.8 & 33.7 & 45.4 & 79.0 \\
\hline 1951 & 87.4 & 49.6 & 37.8 & 65.2 & 103.0 \\
\hline 1952 & 89.0 & 53.8 & 35.2 & 15.7 & 50.9 \\
\hline 1953 & 94.2 & 56.5 & 37.7 & 5.6 & 43.3 \\
\hline 1954 & 93.8 & 59.2 & 34.6 & 4.9 & 39.5 \\
\hline 1955 & 107.1 & 62.3 & 44.8 & 21.6 & 66.4 \\
\hline 1956 & 109.4 & 69.8 & 39.6 & 58.2 & 97.8 \\
\hline 1957 & 114.9 & 76.5 & 38.4 & 52.5 & 90.9 \\
\hline 1958 & 111.2 & 80.8 & 30.4 & 31.6 & 62.1 \\
\hline 1959 & 121.6 & 83.7 & 37.9 & 39.7 & 77.6 \\
\hline 1960 & 122.0 & 86.7 & 35.3 & 32.4 & 67.7 \\
\hline 1961 & 124.6 & 89.7 & 34.9 & 29.2 & 54.1 \\
\hline 1962 & 141.2 & 92.4 & 48.8 & 41.0 & 89.8 \\
\hline 1963 & 147.5 & 96.3 & 51.2 & 37.6 & 88.8 \\
\hline 1964 & 166.1 & 101.5 & 64.6 & 45.6 & 110.3 \\
\hline 1965 & 181.9 & 107.5 & 74.5 & 52.4 & 126.9 \\
\hline 1966 & 204.8 & 115.7 & 89.0 & 64.4 & 153.4 \\
\hline 1967 & 216.1 & 127.2 & 88.9 & 79.1 & 168.1 \\
\hline 1968 & 227.8 & 138.5 & 89.3 & 98.8 & 188.1 \\
\hline 1969 & 233.8 & 152.0 & 81.8 & 120.8 & 202.6 \\
\hline
\end{tabular}


Gross private national capital formation is equal to gross private domestic investment, as defined in the U.S. national accounts, plus personal consumption expenditures on durable goods, plus the current deficits of the federal and state and local social insurance funds, plus the current surpluses of federal and state and local social insurance funds, plus net foreign investment. The components of gross private national saving and gross private national capital formation

TABLE 14

Change in Private National Wealth, 1929-1969 (Current Prices)

\begin{tabular}{|c|c|c|c|c|}
\hline Year & $\begin{array}{l}\text { Change in } \\
\text { Value of } \\
\text { Private } \\
\text { Domestic } \\
\text { Tangible } \\
\text { Assets }\end{array}$ & $\begin{array}{c}\text { Net Capital } \\
\text { Formation, } \\
\text { Private } \\
\text { Domestic } \\
\text { Tangible } \\
\text { Assets }\end{array}$ & $\begin{array}{c}\text { Capital } \\
\text { Gains, } \\
\text { Private } \\
\text { Domestic } \\
\text { Tangible } \\
\text { Assets }\end{array}$ & $\begin{array}{l}\text { Change in } \\
\text { Value of } \\
\text { Net Claims } \\
\text { on Govern } \\
\text { ments and } \\
\text { Foreigners }\end{array}$ \\
\hline 1929 & 9.1 & 6.4 & 2.6 & 0.8 \\
\hline 1930 & -23.4 & -1.6 & -21.8 & 1.0 \\
\hline 1931 & -43.9 & -6.0 & -37.9 & 1.2 \\
\hline 1932 & -48.9 & -10.2 & -38.7 & 2.1 \\
\hline 1933 & -7.2 & -8.5 & 1.3 & 2.1 \\
\hline 1934 & 10.8 & -6.2 & 17.0 & 5.8 \\
\hline 1935 & 2.0 & -1.4 & 3.4 & 2.2 \\
\hline 1936 & 10.9 & 2.0 & 8.8 & 2,6 \\
\hline 1937 & 21.7 & 4.7 & 17.0 & 1.7 \\
\hline 1938 & -3.6 & -2.9 & -0.8 & 2.7 \\
\hline 1939 & 0.9 & 1.5 & -0.5 & 3.4 \\
\hline 1940 & 13.7 & 6.0 & 7.7 & 2.1 \\
\hline 1941 & 37.5 & 11.1 & 26.4 & 10.6 \\
\hline 1942 & 32.8 & -3.0 & 35.7 & 39.7 \\
\hline 1943 & 20.3 & -8.1 & 28.4 & 44.9 \\
\hline 1944 & 20.6 & -7.8 & 28.4 & 47.7 \\
\hline 1945 & 16.0 & -3.8 & 19.8 & 36.3 \\
\hline 1946 & 73.2 & 23.2 & 50.0 & 5.3 \\
\hline 1947 & 111.9 & 26.0 & 86.0 & -4.2 \\
\hline 1948 & 81.5 & 34.1 & 47.4 & -4.0 \\
\hline 1949 & 10.9 & 22.3 & -11.4 & 6.5 \\
\hline 1950 & 83.6 & 43.1 & 40.4 & -4.1 \\
\hline 1951 & 103.5 & 39.5 & 64.0 & -0.5 \\
\hline 1952 & 42.9 & 27.2 & 15.7 & 7.8 \\
\hline 1953 & 32.8 & 29.9 & 2.9 & 11.0 \\
\hline 1954 & 28.5 & 25.0 & 3.5 & 10.6 \\
\hline 1955 & 65.1 & 44.7 & 20.4 & 1.2 \\
\hline 1956 & 94.9 & 39.1 & 55.7 & 2.9 \\
\hline 1957 & 83.1 & 31.9 & 51.2 & 7.5 \\
\hline 1958 & 46.6 & 18.0 & 28.6 & 15.4 \\
\hline 1959 & 71.8 & 36.1 & 35.6 & 6.0 \\
\hline 1960 & 61.4 & 33.3 & 28.1 & 6.1 \\
\hline 1961 & 54.4 & 26.2 & 28.2 & 9.9 \\
\hline 1962 & 78.0 & 40.1 & 37.9 & 11.7 \\
\hline 1963 & 81.4 & 44.7 & 36.8 & 7.2 \\
\hline 1964 & 99.3 & 52.0 & 47.3 & 11.2 \\
\hline 1965 & 117.5 & 66.6 & 50.9 & 8.9 \\
\hline 1966 & 141.0 & 76.3 & 64.7 & 12.3 \\
\hline 1967 & 146.9 & 62.5 & 84.5 & 21.1 \\
\hline 1968 & 172.0 & 71.5 & 100.5 & 15.4 \\
\hline 1969 & 196.3 & 77.5 & 118.8 & 5.9 \\
\hline
\end{tabular}


TABLE 14 continued

\begin{tabular}{|c|c|c|c|}
\hline Year & $\begin{array}{l}\text { Net Capital } \\
\text { Formation, } \\
\text { Net Claims } \\
\text { on Govern- } \\
\text { ments and } \\
\text { Rest of World }\end{array}$ & $\begin{array}{c}\text { Capital Gains, } \\
\text { Net Claims } \\
\text { on Govern- } \\
\text { ments and } \\
\text { Rest of World }\end{array}$ & $\begin{array}{c}\text { Change in } \\
\text { Private } \\
\text { National } \\
\text { Wealth }\end{array}$ \\
\hline 1929 & -0.0 & 0.8 & 9.7 \\
\hline 1930 & 1.2 & -0.2 & -22.4 \\
\hline 1931 & 3.2 & -2.1 & -42.7 \\
\hline 1932 & 2.1 & 0.0 & -46.7 \\
\hline 1933 & 1.7 & 0.4 & -5.0 \\
\hline 1934 & 3.0 & 2.8 & 16.9 \\
\hline 1935 & 2.1 & 0.1 & 4.2 \\
\hline 1936 & 3.4 & -0.8 & 13.3 \\
\hline 1937 & 1.3 & 0.4 & 23.2 \\
\hline 1938 & 4.1 & -1.4 & -0.7 \\
\hline 1939 & 4.4 & -1.0 & 4.3 \\
\hline 1940 & 3.5 & -1.4 & 15.7 \\
\hline 1941 & 6.9 & 3.8 & 47.8 \\
\hline 1942 & 33.8 & 5.9 & 72.0 \\
\hline 1943 & 45.8 & -0.8 & 64.7 \\
\hline 1944 & 54.3 & -6.6 & 68.3 \\
\hline 1945 & 43.0 & -6.7 & 53.0 \\
\hline 1946 & 3.0 & 2.3 & 78.8 \\
\hline 1947 & -1.6 & -2.6 & 107.8 \\
\hline 1948 & -3.3 & -0.7 & 78.2 \\
\hline 1949 & 6.3 & 0.2 & 17.6 \\
\hline 1950 & -9.1 & 5.0 & 79.0 \\
\hline 1951 & -1.6 & 1.1 & 103.0 \\
\hline 1952 & 7.7 & 0.0 & 50.9 \\
\hline 1953 & 8.3 & 2.7 & 43.3 \\
\hline 1954 & 9.3 & 1.4 & 39.5 \\
\hline 1955 & 0.1 & 1.1 & 66.4 \\
\hline 1956 & 0.5 & 2.5 & 97.8 \\
\hline 1957 & 6.2 & 1.3 & 90.9 \\
\hline 1958 & 12.4 & 3.0 & 62.1 \\
\hline 1959 & 1.9 & 4.1 & 77.6 \\
\hline 1960 & 1.8 & 4.3 & 67.7 \\
\hline 1961 & 8.9 & 1.0 & 64.1 \\
\hline 1962 & 8.7 & 3.1 & 89.8 \\
\hline 1963 & 6.4 & 0.9 & 88.8 \\
\hline 1964 & 12.8 & -1.7 & 110.3 \\
\hline 1965 & 7.5 & 1.5 & 126.9 \\
\hline 1966 & 12.5 & -0.3 & 153.4 \\
\hline 1967 & 26.4 & -5.3 & 168.1 \\
\hline 1968 & 17.2 & -1.7 & 188.1 \\
\hline 1969 & 3.9 & 2.0 & 202.6 \\
\hline
\end{tabular}

for 1958 are presented in Table 12, along with replacement, depreciation, and revaluation. Annual estimates are presented in Table 13. The annual change in wealth can be represented as net capital formation plus capital gains. Annual estimates of these magnitudes for private domestic tangible assets and for net claims on the government and rest of world sectors are presented in Table 14. 


\subsection{Capital Formation}

We divide the components of gross private national capital formation into prices and quantities using the following deflators: The implicit deflators from the U.S. National Income and Product Accounts are used for investment in producer and consumer durables and in farm and nonfarm inventories. For residential and non-residential structures we use the "constant cost 2" price index for structures from the Bureau of Economic Analysis Capital Stock Study for both capital formation and replacement. ${ }^{22}$ We have constructed price indexes for claims on the government and rest of world sectors from data on changes in the value of claims from period to period and data on the corresponding components of capital formation from the U.S. national accounts. We set the price of claims of each type equal to 1.000 in 1958 and the quantity in 1958 equal to the value of outstanding claims in that year. These price indexes are then used to deflate the government deficit and net foreign investment.

To construct an index of the quantity of gross private national capital formation we first construct a Divisia index of the quantities of investment in producer and consumer durables, residential and nonresidential structures, and the quantity indexes of net foreign investment and government deficits. Real investment in inventories of durable and nondurable goods are added to the Divisia index to obtain the quantity index of gross private national capital formation. The price index of replacement is computed as the ratio of the value of replacement to the Divisia index of replacement. The price and quantity indexes of gross private national capital formation and replacement are presented in Table 15.

\subsection{Accumulation and Revaluation}

The value of gross private national saving is taken from the income and expenditure account. To construct the saving side of the accumulation account in constant prices we begin with gross private national capital formation in constant prices. The capital formation and saving sides of the accumulation account are equal in both current and constant prices. To complete the accumulation and revaluation account in constant prices we must construct accounts for depreciation and revaluation of assets in constant prices.

If the decline in efficiency of capital goods is geometric the change in wealth from period to period for a single capital good may be written:

$$
\begin{aligned}
W_{t}-W_{t-1} & =q_{A, t} K_{t}-q_{A, t-1} K_{t-1}, \\
& =q_{A, t}\left(K_{t}-K_{t-1}\right)+\left(q_{A, t}-q_{A, t-1}\right) K_{t-1}, \\
& =q_{A, t} A_{t}-q_{A, t} \delta K_{t-1}+\left(q_{A, t}-q_{A, t-1}\right) K_{t-1} .
\end{aligned}
$$

Gross saving is represented by $q_{A, t} A_{t}$, which is equal to gross capital formation and has the same price and quantity components. Depreciation is represented by $q_{A, t} \delta K_{t-1}$ and is equal to replacement; the price and quantity components of depreciation differ from the price and quantity components of replacement.

${ }^{22}$ The Bureau of Economic Analysis Capital Stock Study is reported in a series of articles. See Grose, Rottenberg, and Wasson (1969) and the references given there. We are indebted to Robert Wasson for permission to use the underlying data on investment in current and constant prices. 
TABLE 15

Gross Private National Capital Formation, 1929-1969

(Constant Prices of 1958)

\begin{tabular}{|c|c|c|c|c|}
\hline Year & $\begin{array}{c}\text { Gross } \\
\text { Private } \\
\text { National } \\
\text { Capital } \\
\text { Formation, } \\
\text { Price Index }\end{array}$ & $\begin{array}{c}\text { Gross } \\
\text { Private } \\
\text { National } \\
\text { Capital } \\
\text { Formation, } \\
\text { Quantity } \\
\text { Index }\end{array}$ & $\begin{array}{l}\text { Replacement, } \\
\text { Price Index }\end{array}$ & $\begin{array}{c}\text { Replacement, } \\
\text { Quantity } \\
\text { Index }\end{array}$ \\
\hline 1929 & 0.474 & 53.6 & 0.463 & 41.3 \\
\hline 1930 & 0.473 & 39.3 & 0.449 & 42.3 \\
\hline 1931 & 0.471 & 30.5 & 0.411 & 41.8 \\
\hline 1932 & 0.441 & 15.2 & 0.365 & 40.2 \\
\hline 1933 & 0.423 & 15.5 & 0.352 & 37.7 \\
\hline 1934 & 0.483 & 21.8 & 0.379 & 35.5 \\
\hline 1935 & 0.429 & 31.8 & 0.379 & 34.1 \\
\hline 1936 & 0.436 & 41.8 & 0.381 & 33.8 \\
\hline 1937 & 0.434 & 46.1 & 0.408 & 34.6 \\
\hline 1938 & 0.490 & 33.2 & 0.416 & 35.7 \\
\hline 1939 & 0.467 & 43.4 & 0.410 & 35.3 \\
\hline 1940 & 0.460 & 53.2 & 0.418 & 35.8 \\
\hline 1941 & 0.510 & 67.5 & 0.453 & 37.2 \\
\hline 1942 & 0.765 & 66.1 & 0.516 & 39.2 \\
\hline 1943 & 0.848 & 68.5 & 0.551 & 38.0 \\
\hline 1944 & 0.861 & 79.1 & 0.595 & 36.4 \\
\hline 1945 & 0.822 & 75.0 & 0.617 & 35.2 \\
\hline 1946 & 0.661 & 74.6 & 0.655 & 35.0 \\
\hline 1947 & 0.728 & 72.5 & 0.741 & 38.3 \\
\hline 1948 & 0.798 & 82.0 & 0.792 & 42.9 \\
\hline 1949 & 0.809 & 82.4 & 0.799 & 47.4 \\
\hline 1950 & 0.803 & 94.1 & 0.817 & 51.2 \\
\hline 1951 & 0.885 & 98.8 & 0.880 & 56.3 \\
\hline 1952 & 0.906 & 98.3 & 0.898 & 59.9 \\
\hline 1953 & 0.903 & 104.2 & 0.901 & 62.7 \\
\hline 1954 & 0.906 & 103.6 & 0.895 & 66.2 \\
\hline 1955 & 0.904 & 118.4 & 0.901 & 69.2 \\
\hline 1956 & 0.949 & 115.3 & 0.945 & 73.9 \\
\hline 1957 & 0.989 & 116.2 & 0.986 & 77.6 \\
\hline 1958 & 1.000 & 111.2 & 1.000 & 80.8 \\
\hline 1959 & 1.017 & 119.5 & 1.017 & 82.2 \\
\hline 1960 & 1.020 & 119.5 & 1.018 & 85.2 \\
\hline 1961 & 1.018 & 122.4 & 1.017 & 88.2 \\
\hline 1962 & 1.027 & 137.5 & 1.023 & 90.3 \\
\hline 1963 & 1.030 & 143.2 & 1.026 & 93.8 \\
\hline 1964 & 1.040 & 159.8 & 1.035 & 98.1 \\
\hline 1965 & 1.048 & 173.6 & 1.040 & 103.4 \\
\hline 1966 & 1.059 & 193.4 & 1.051 & 110.2 \\
\hline 1967 & 1.081 & 199.9 & 1.080 & 117.7 \\
\hline 1968 & 1.117 & 204.0 & 1.116 & 124.2 \\
\hline 1969 & 1.164 & 200.9 & 1.155 & 131.6 \\
\hline
\end{tabular}

We construct the quantity index of depreciation as a Divisia index of the quantities of lagged capital stocks with depreciation shares as weights. The quantity index of replacement is a Divisia index of the quantities of replacement with replacement shares as weights. Under geometric decline in efficiency the weights 
are the same for replacement and depreciation, so that the quantity indexes for depreciation and replacement are proportional. The price index of depreciation is computed as the ratio of depreciation to the quantity index of depreciation.

Revaluation is represented by $\left(q_{A, t}-q_{A, t-1}\right) K_{t-1}$. We construct a quantity index of revaluation as a Divisia index of the various lagged capital stocks with

TABLE 16

Gross Private National Saving, Depreciation, and Revaluation, 1929-1969

(Constant Prices of 1958)

\begin{tabular}{|c|c|c|c|c|c|c|}
\hline Year & $\begin{array}{c}\text { Gross } \\
\text { Private } \\
\text { National } \\
\text { Saving, } \\
\text { Price Index }\end{array}$ & $\begin{array}{c}\text { Gross } \\
\text { Private } \\
\text { National } \\
\text { Saving, } \\
\text { Quantity } \\
\text { Index }\end{array}$ & $\begin{array}{c}\text { Depreciation, } \\
\text { Price Index }\end{array}$ & $\begin{array}{c}\text { Depreciation, } \\
\text { Quantity } \\
\text { Index }\end{array}$ & $\begin{array}{l}\text { Revaluation, } \\
\text { Price Index }\end{array}$ & $\begin{array}{c}\text { Revaluation, } \\
\text { Quantity } \\
\text { Index }\end{array}$ \\
\hline 1929 & 0.474 & 53.6 & 0.046 & 418.3 & 0.003 & $1200 \cdot 3$ \\
\hline 1930 & 0.473 & 39.3 & 0.044 & 428.3 & -0.018 & 1214.8 \\
\hline 1931 & 0.471 & 30.5 & 0.041 & 422.8 & -0.033 & 1212.2 \\
\hline 1932 & 0.441 & 15.2 & 0.036 & 407.1 & -0.032 & 1200.5 \\
\hline 1933 & 0.423 & 15.5 & 0.035 & 381.3 & 0.001 & 1293.4 \\
\hline 1934 & 0.483 & 21.8 & 0.037 & 359.2 & 0.015 & 1361.8 \\
\hline 1935 & 0.429 & 31.8 & 0.037 & 345.4 & 0.003 & 1298.2 \\
\hline 1936 & 0.436 & 41.8 & 0.038 & 342.1 & 0.006 & 1301.3 \\
\hline 1937 & 0.434 & 46.1 & 0.040 & 350.3 & 0.013 & 1299.7 \\
\hline 1938 & 0.490 & 33.2 & 0.041 & 361.3 & -0.002 & 1384.7 \\
\hline 1939 & 0.467 & 43.4 & 0.041 & 357.6 & -0.001 & 1445.9 \\
\hline 1940 & 0.460 & 53.2 & 0.041 & 362.6 & 0.004 & 1491.5 \\
\hline 1941 & 0.510 & 67.5 & 0.045 & 376.3 & 0.020 & 1514.1 \\
\hline 1942 & 0.765 & 66.1 & 0.051 & 396.8 & 0.026 & 1581.3 \\
\hline 1943 & 0.848 & 68.5 & 0.054 & 384.6 & 0.017 & 1598.6 \\
\hline 1944 & 0.861 & 79.1 & 0.059 & 368.4 & 0.015 & 1470.6 \\
\hline 1945 & 0.822 & 75.0 & 0.061 & 355.7 & 0.010 & 1260.3 \\
\hline 1946 & 0.661 & 74.6 & 0.065 & 354.4 & 0.044 & 1188.0 \\
\hline 1947 & 0.728 & 72.5 & 0.073 & 387.8 & 0.067 & 1235.3 \\
\hline 1948 & 0.798 & 82.0 & 0.078 & 433.9 & 0.036 & 1287.3 \\
\hline 1949 & 0.809 & 82.4 & 0.079 & 479.4 & -0.008 & 1317.4 \\
\hline 1950 & 0.803 & 94.1 & 0.081 & 518.1 & 0.035 & 1314.2 \\
\hline 1951 & 0.885 & 98.8 & 0.087 & 570.0 & 0.048 & 1367.2 \\
\hline 1952 & 0.906 & 98.3 & 0.089 & 606.5 & 0.011 & 1411.0 \\
\hline 1953 & 0.903 & 104.2 & 0.089 & 634.2 & 0.004 & 1456.7 \\
\hline 1954 & 0.906 & 103.6 & 0.088 & 670.0 & 0.003 & 1469.6 \\
\hline 1955 & 0.904 & 118.4 & 0.089 & 699.7 & 0.015 & 1446.6 \\
\hline 1956 & 0.949 & 115.3 & 0.093 & 747.6 & 0.039 & 1489.3 \\
\hline 1957 & 0.989 & 116.2 & 0.097 & 785.1 & 0.034 & 1534.5 \\
\hline 1958 & 1.000 & 111.2 & 0.099 & 817.7 & 0.020 & 1564.2 \\
\hline 1959 & 1.017 & 119.5 & 0.101 & 832.1 & 0.025 & 1581.2 \\
\hline 1960 & 1.020 & 119.5 & 0.101 & 862.1 & 0.020 & 1599.1 \\
\hline 1961 & 1.018 & 122.4 & 0.101 & 892.3 & 0.018 & 1603.7 \\
\hline 1962 & 1.027 & 137.5 & 0.101 & 913.9 & 0.025 & 1613.3 \\
\hline 1963 & 1.030 & 143.2 & 0.101 & 949.4 & 0.023 & 1627.5 \\
\hline 1964 & 1.040 & 159.8 & 0.102 & 992.2 & 0.028 & 1641.8 \\
\hline 1965 & 1.048 & 173.6 & 0.103 & 1045.7 & 0.032 & 1659.1 \\
\hline 1966 & 1.059 & 193.4 & 0.104 & 1114.7 & 0.038 & 1684.7 \\
\hline 1967 & 1.081 & 199.9 & 0.107 & 1190.9 & 0.046 & 1721.1 \\
\hline 1968 & 1.117 & 204.0 & 0.110 & 1256.4 & 0.056 & 1751.6 \\
\hline 1969 & 1.164 & 200.9 & 0.114 & 1331.9 & 0.067 & 1791.3 \\
\hline
\end{tabular}


revaluation shares as weights. The price index of revaluation is computed as the ratio of revaluation to the quantity index of revaluation. Price and quantity index numbers of gross private national saving, depreciation, and revaluation are presented in Table 16 .

\subsection{Standard of Living}

At this point we can consolidate the receipt and expenditure account with the accumulation account to obtain a consolidated receipt and expenditure account. In the consolidated account consumer receipts are equal to the sum of consumer outlays and gross capital formation. Price and quantity index numbers for factor income can be constructed by combining Divisia index numbers of labor and property income into a Divisia index of factor income. The weights for labor and property are the relative shares of labor and property compensation in the value of total factor income. We use the price index of factor income to deflate government transfer payments to persons other than social insurance benefits. Adding deflated transfer payments to the quantity index of factor income provides an index of total real consumer receipts. The construction of an index of total real consumer receipts is analogous to the construction of an index of total factor input in the production account; the scope of transactions covered by the two indexes is different and consumer receipts are net of both direct and indirect taxes in the consolidated consumer receipts and expenditures account.

Price and quantity index numbers for total expenditures can be constructed by combining Divisia index numbers of consumer outlays and capital formation into a Divisia index of total expenditures. The weights for consumer outlays and capital formation are the relative shares of these components of expenditure in the value of total expenditure. The price and quantity indexes of expenditures are analogous to indexes for total product in the production account; the scope of transactions is different and expenditures includes sales and excise taxes, while the value of total product excludes such taxes.

The standard of living may be defined as the ratio of real expenditures to real receipts or, equivalently, the ratio of the price of factor income to the price of expenditures. A Divisia index of the standard of living may be defined as the ratio of Divisia indexes of the quantity of expenditures to the quantity of consumer receipts or, equivalently, the ratio of Divisia indexes of the price of factor income to the price of consumer expenditures. Divisia price and quantity indexes of consumer receipts and total expenditures and the standard of living for the U.S. private national economy are given in Table 17 for 1929-1969.

\section{Private National Wealth}

\subsection{Introduction}

We now describe accounts for the wealth of private households and institutions and its distribution as claims against the producing sector and the foreign sector and the government sectors. The tangible assets of private households and institutions are included among the assets of the producing sector. Total claims against the producing sector by private households and institutions are equal 
TABLE 17

Gross Private National Expenditures, Receipts, and Standard of Living, 1929-1969 (CONSTANt Prices of 1958)

\begin{tabular}{|c|c|c|c|c|c|}
\hline Year & $\begin{array}{c}\text { Gross } \\
\text { Private } \\
\text { National } \\
\text { Expenditures, } \\
\text { Price Index }\end{array}$ & $\begin{array}{c}\text { Gross } \\
\text { Private } \\
\text { National } \\
\text { Expenditures, } \\
\text { Quantity } \\
\text { Index }\end{array}$ & $\begin{array}{c}\text { Gross } \\
\text { Private } \\
\text { National } \\
\text { Consumer } \\
\text { Receipts, } \\
\text { Price Index }\end{array}$ & $\begin{array}{c}\text { Gross } \\
\text { Private } \\
\text { National } \\
\text { Consumer } \\
\text { Receipts, } \\
\text { Quantity } \\
\text { Index }\end{array}$ & $\begin{array}{c}\text { Standard } \\
\text { of Living } \\
\text { Index }\end{array}$ \\
\hline 1929 & 0.531 & 194.8 & 0.346 & 298.8 & 0.652 \\
\hline 1930 & 0.516 & 176.3 & 0.303 & 300.4 & 0.587 \\
\hline 1931 & 0.479 & 164.3 & 0.259 & 304.3 & 0.540 \\
\hline 1932 & 0.416 & 138.1 & 0.193 & 297.1 & 0.465 \\
\hline 1933 & 0.416 & 135.8 & 0.191 & 296.7 & 0.458 \\
\hline 1934 & 0.444 & 146.5 & 0.230 & 283.6 & 0.517 \\
\hline 1935 & 0.443 & 159.6 & 0.245 & 288.8 & 0.553 \\
\hline 1936 & 0.453 & 180.4 & 0.271 & 301.9 & 0.598 \\
\hline 1937 & 0.461 & 189.2 & 0.289 & 301.7 & 0.627 \\
\hline 1938 & 0.464 & 177.4 & 0.273 & 301.8 & 0.588 \\
\hline 1939 & 0.459 & 192.9 & 0.290 & 305.6 & 0.631 \\
\hline 1940 & 0.459 & 208.5 & 0.310 & 308.6 & 0.676 \\
\hline 1941 & 0.493 & 230.9 & 0.356 & 319.7 & 0.722 \\
\hline 1942 & 0.594 & 233.0 & 0.413 & 335.1 & 0.695 \\
\hline 1943 & 0.672 & 241.0 & 0.451 & 358.8 & 0.672 \\
\hline 1944 & 0.695 & 259.9 & 0.498 & 363.0 & 0.716 \\
\hline 1945 & 0.704 & 263.9 & 0.529 & 351.1 & 0.752 \\
\hline 1946 & 0.710 & 272.3 & 0.582 & 332.5 & 0.819 \\
\hline 1947 & 0.782 & 272.0 & 0.632 & 336.6 & 0.808 \\
\hline 1948 & 0.827 & 287.7 & 0.693 & 343.5 & 0.837 \\
\hline 1949 & 0.801 & 293.1 & 0.674 & 348.4 & 0.841 \\
\hline 1950 & 0.832 & 314.6 & 0.735 & 355.6 & 0.885 \\
\hline 1951 & 0.882 & 328.3 & 0.783 & 369.9 & 0.887 \\
\hline 1952 & 0.908 & 337.1 & 0.808 & 378.9 & 0.890 \\
\hline 1953 & 0.919 & 352.0 & 0.846 & 382.6 & 0.920 \\
\hline 1954 & 0.924 & 358.2 & 0.861 & 384.3 & 0.932 \\
\hline 1955 & 0.938 & 385.8 & 0.920 & 393.3 & 0.981 \\
\hline 1956 & 0.955 & 395.6 & 0.937 & 402.9 & 0.982 \\
\hline 1957 & 0.978 & 405.0 & 0.977 & 405.7 & 0.998 \\
\hline 1958 & 1.000 & 407.7 & 1.000 & 407.7 & 1.000 \\
\hline 1959 & 1.027 & 428.6 & 1.063 & 414.2 & 1.035 \\
\hline 1960 & 1.043 & 438.0 & 1.081 & 422.5 & 1.037 \\
\hline 1961 & 1.047 & 450.0 & 1.101 & 427.6 & 1.052 \\
\hline 1962 & 1.059 & 477.3 & 1.166 & 433.5 & 1.101 \\
\hline 1963 & 1.074 & 496.0 & 1.205 & 441.9 & 1.123 \\
\hline 1964 & 1.088 & 530.9 & 1.277 & 452.2 & 1.174 \\
\hline 1965 & 1.101 & 564.3 & 1.329 & 467.2 & 1.208 \\
\hline 1966 & 1.128 & 603.9 & 1.404 & 485.4 & 1.244 \\
\hline 1967 & 1.150 & 627.7 & 1.432 & 504.1 & 1.245 \\
\hline 1968 & 1.186 & 650.7 & 1.483 & 520.2 & 1.251 \\
\hline 1969 & 1.240 & 665.9 & 1.534 & 538.2 & 1.237 \\
\hline
\end{tabular}

to the value of the tangible assets of the producing sector plus net claims against foreign and government sectors by the producing sector. The remainder of private wealth consists of claims against the foreign and government sectors by private households and institutions. Total wealth is the sum of private domestic tangible 
assets and net claims against the foreigners and government sectors. Private national wealth is the value of private domestic tangible assets plus net claims on foreigners and governments including claims held by the producing sector and claims held directly by private households and institutions. The value of private domestic tangible assets is simply the stock of all such assets, evaluated at current prices.

\subsection{Wealth in Current Prices}

Our measurement of net claims on foreigners and governments is based on the flow of funds accounts of the Board of Governors of the Federal Reserve System, ${ }^{23}$ Studies in the National Balance Sheet of the United States and The National Wealth of the United States in the Postwar Period by Raymond Goldsmith. ${ }^{24}$ We distinguish between monetary and non-monetary claims on the federal government by the private sector. Monetary claims include vault cash of commercial banks, member bank reserves, and currency outside banks. ${ }^{25}$ Non-monetary claims on the federal government include U.S. government total

TABLE 18

Private National Wealth, 1958 (Current Prices)

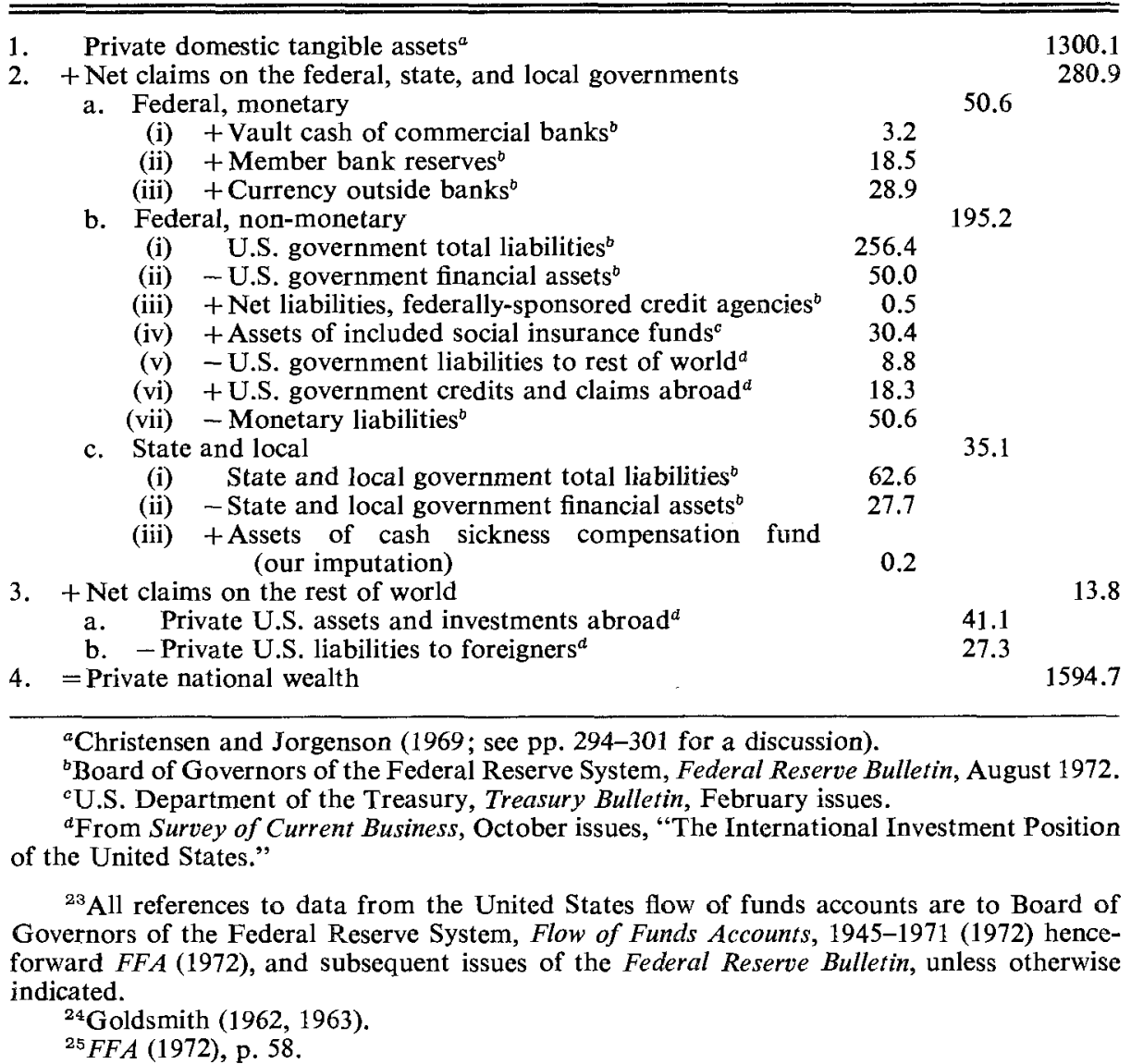


TABLE 19

Private National Wealth, 1929-1969 (Current Prices)

\begin{tabular}{|c|c|c|c|c|c|}
\hline Year & $\begin{array}{c}\text { Corporate } \\
\text { Tangible } \\
\text { Assets }\end{array}$ & $\begin{array}{c}\text { Non- } \\
\text { Corporate } \\
\text { Tangible } \\
\text { Assets }\end{array}$ & $\begin{array}{l}\text { Household } \\
\text { and } \\
\text { Institutional } \\
\text { Tangible } \\
\text { Assets }\end{array}$ & $\begin{array}{l}\text { Net Claims } \\
\text { on } \\
\text { Governments } \\
\text { and Rest of } \\
\text { World }\end{array}$ & $\begin{array}{c}\text { Private } \\
\text { National } \\
\text { Wealth }\end{array}$ \\
\hline 1929 & 116.7 & 106.7 & 158.1 & 33.0 & 414.6 \\
\hline 1930 & 110.3 & 97.9 & 150.0 & 34.0 & 392.2 \\
\hline 1931 & 97.7 & 85.1 & 131.5 & 35.2 & 349.5 \\
\hline 1932 & 84.1 & 73.3 & 108.1 & 37.3 & 302.7 \\
\hline 1933 & 80.4 & 73.4 & 104.4 & 39.4 & 297.6 \\
\hline 1934 & 83.1 & 76.3 & 109.5 & 45.2 & 314.2 \\
\hline 1935 & 83.7 & 79.4 & 107.9 & 47.4 & 318.3 \\
\hline 1936 & 86.6 & 82.7 & 112.5 & 50.0 & 331.8 \\
\hline 1937 & 95.0 & 88.1 & 120.5 & 51.7 & 355.2 \\
\hline 1938 & 92.2 & $\begin{array}{l}00.1 \\
85.6\end{array}$ & 122.2 & 54.4 & 354.3 \\
\hline 1939 & 91.9 & 85.3 & 123.6 & 57.8 & 358.6 \\
\hline 1940 & 96.6 & 88.7 & 129.2 & 59.9 & 374.4 \\
\hline 1941 & 109.7 & 98.6 & 143.7 & 70.5 & 422.5 \\
\hline 1942 & 121.1 & 108.6 & 155.1 & 110.3 & 495.0 \\
\hline 1943 & 126.4 & 115.1 & 163.6 & 155.2 & 560.2 \\
\hline 1944 & 130.4 & 121.2 & 173.9 & 202.9 & 628.5 \\
\hline 1945 & 133.1 & 127.2 & 181.2 & 239.2 & 680.8 \\
\hline 1946 & 159.6 & 148.5 & 206.7 & 244.5 & 759.3 \\
\hline 1947 & 199.1 & 175.0 & 252.6 & 240.3 & 867.0 \\
\hline 1948 & 224.2 & 192.2 & 291.8 & 236.3 & 944.5 \\
\hline 1949 & 226.6 & 190.4 & 302.1 & 242.8 & 962.0 \\
\hline 1950 & 248.2 & 212.7 & 341.8 & 238.7 & 1041.4 \\
\hline 1951 & 286.9 & 234.4 & 384.9 & 238.2 & 1144.5 \\
\hline 1952 & 303.0 & 237.5 & 408.7 & 246.0 & 1195.1 \\
\hline 1953 & 315.5 & 238.6 & 427.8 & 257.0 & 1238.9 \\
\hline 1954 & 323.1 & 244.4 & 442.9 & 267.6 & 1278.0 \\
\hline 1955 & 344.3 & 253.5 & 477.6 & 268.8 & 1344.2 \\
\hline 1956 & 381.8 & 269.7 & 518.8 & 271.7 & 1442.0 \\
\hline 1957 & 411.9 & 287.8 & 553.8 & 279.2 & 1532.7 \\
\hline 1958 & 422.2 & 303.9 & 574.0 & 294.7 & 1594.7 \\
\hline 1959 & 443.7 & 315.4 & 612.8 & 300.7 & 1672.5 \\
\hline 1960 & 461.9 & 330.6 & 640.7 & 306.8 & 1740.1 \\
\hline 1961 & 476.6 & 347.3 & 663.8 & 316.7 & 1804.4 \\
\hline 1962 & 500.1 & 367.0 & 698.6 & 328.5 & 1894.1 \\
\hline 1963 & 524.4 & 384.7 & 737.9 & 335.7 & 1982.8 \\
\hline 1964 & 556.4 & 404.8 & 785.1 & 346.9 & 2093.3 \\
\hline 1965 & 598.9 & 433.9 & 831.1 & 355.8 & 2219.7 \\
\hline 1966 & 660.0 & 464.2 & 880.6 & 368.1 & 2372.9 \\
\hline 1967 & 714.8 & 494.0 & 943.0 & 389.2 & 2540.9 \\
\hline 1968 & 771.4 & 529.5 & 1022.9 & 404.6 & 2728.4 \\
\hline 1969 & 839.8 & 570.8 & 1109.5 & 410.5 & 2930.6 \\
\hline
\end{tabular}

liabilities, less U.S. government financial assets, net liabilities of federally sponsored credit agencies, ${ }^{26}$ financial assets of included social insurance funds, ${ }^{27}$ less

${ }^{26} F F A$ (1972), p. 56.

${ }^{27}$ The flow of funds of accounts include some social insurance funds in the government sector; the rest are treated as part of the private sector. We include all social insurance funds in the private sector; for this purpose we include the assets of all social insurance funds among claims on the government by the private sector. We include the assets of the OASI, disability, medical trust funds, and the unemployment trust funds; we use the December figure from the Treasury Bulletin. 
U.S. government liabilities to rest of world, U.S. government credits and claims abroad, less monetary liabilities. ${ }^{28}$ Private sector claims on state and local governments include state and local government total liabilities, less state and local

TABLE 20

Private National Wealth, 1929-1969 (Constant Prices of 1958)

\begin{tabular}{|c|c|c|c|c|c|c|}
\hline Year & $\begin{array}{c}\text { Corporate } \\
\text { Tangible } \\
\text { Assets, } \\
\text { Price Index }\end{array}$ & $\begin{array}{l}\text { Corporate } \\
\text { Tangible } \\
\text { Assets, } \\
\text { Quantity } \\
\text { Index }\end{array}$ & $\begin{array}{c}\text { Non- } \\
\text { Corporate } \\
\text { Tangible } \\
\text { Assets, } \\
\text { Price Index }\end{array}$ & $\begin{array}{c}\text { Non- } \\
\text { Corporate } \\
\text { Tangible } \\
\text { Assets, } \\
\text { Quantity } \\
\text { Index }\end{array}$ & $\begin{array}{c}\text { Household } \\
\text { and } \\
\text { Institutional } \\
\text { Tangible } \\
\text { Assets, } \\
\text { Price Index }\end{array}$ & $\begin{array}{c}\text { Household } \\
\text { and } \\
\text { Institutional } \\
\text { Tangible } \\
\text { Assets, } \\
\text { Quantity } \\
\text { Index }\end{array}$ \\
\hline 1929 & 0.424 & 275.3 & 0.417 & 256.2 & 0.427 & 370.7 \\
\hline 1930 & 0.399 & 276.4 & 0.382 & 256.0 & 0.410 & 366.1 \\
\hline 1931 & 0.364 & 268.2 & 0.333 & 255.1 & 0.366 & 358.8 \\
\hline 1932 & 0.332 & 253.5 & 0.293 & 250.4 & 0.312 & 346.7 \\
\hline 1933 & 0.331 & 242.6 & 0.299 & 245.6 & 0.311 & 335.3 \\
\hline 1934 & 0.350 & 237.5 & 0.318 & 240.3 & 0.335 & 327.5 \\
\hline 1935 & 0.357 & 234.6 & 0.328 & 242.2 & 0.332 & 324.5 \\
\hline 1936 & 0.363 & 238.6 & 0.341 & 242.5 & 0.345 & 325.9 \\
\hline 1937 & 0.388 & 244.8 & 0.356 & 247.0 & 0.368 & 327.9 \\
\hline 1938 & 0.384 & 240.2 & 0.348 & 246.2 & 0.375 & 325.6 \\
\hline 1939 & 0.382 & 240.6 & 0.345 & 247.1 & 0.376 & 328.4 \\
\hline 1940 & 0.390 & 247.7 & 0.355 & 249.7 & 0.387 & 334.3 \\
\hline 1941 & 0.420 & 260.9 & 0.387 & 254.7 & 0.419 & 342.9 \\
\hline 1942 & 0.465 & 260.3 & 0.425 & 255.3 & 0.461 & 336.5 \\
\hline 1943 & 0.494 & 255.8 & 0.456 & 252.5 & 0.500 & 327.2 \\
\hline 1944 & 0.518 & 251.6 & 0.482 & 251.6 & 0.547 & 317.7 \\
\hline 1945 & 0.528 & 251.8 & 0.506 & 251.2 & 0.582 & 311.4 \\
\hline 1946 & 0.587 & 271.7 & 0.582 & 255.0 & 0.633 & 326.7 \\
\hline 1947 & 0.696 & 286.0 & 0.680 & 257.5 & 0.728 & 346.9 \\
\hline 1948 & 0.746 & 300.8 & 0.722 & 266.2 & 0.793 & 368.1 \\
\hline 1949 & 0.742 & 305.5 & 0.705 & 270.2 & 0.778 & 388.3 \\
\hline 1950 & 0.773 & 321.2 & 0.764 & 278.6 & 0.816 & 418.9 \\
\hline 1951 & 0.840 & 341.5 & 0.824 & 284.4 & 0.877 & 439.0 \\
\hline 1952 & 0.857 & 353.4 & 0.827 & 287.2 & 0.897 & 455.4 \\
\hline 1953 & 0.866 & 364.2 & 0.822 & 290.3 & 0.900 & 475.4 \\
\hline 1954 & 0.873 & 370.0 & 0.835 & 292.7 & 0.894 & 495.4 \\
\hline 1955 & 0.891 & 386.5 & 0.853 & 297.1 & 0.911 & 524.5 \\
\hline 1956 & 0.942 & 405.2 & 0.901 & 299.2 & 0.952 & 545.0 \\
\hline 1957 & 0.985 & 418.1 & 0.953 & 302.0 & 0.985 & 562.0 \\
\hline 1958 & 1.000 & 422.2 & 1.000 & 303.9 & 1.000 & 574.0 \\
\hline 1959 & 1.021 & 434.5 & 1.028 & 306.7 & 1.031 & 594.2 \\
\hline 1960 & 1.033 & 447.4 & 1.069 & 309.2 & 1.049 & 611.0 \\
\hline 1961 & 1.044 & 456.5 & 1.115 & 311.3 & 1.063 & 624.5 \\
\hline 1962 & 1.062 & 470.8 & 1.164 & 315.2 & 1.086 & 643.6 \\
\hline 1963 & 1.079 & 486.0 & 1.207 & 318.7 & 1.109 & 665.4 \\
\hline 1964 & 1.101 & 505.3 & 1.255 & 322.4 & 1.140 & 688.7 \\
\hline 1965 & 1.129 & 530.5 & 1.322 & 328.3 & 1.162 & 715.3 \\
\hline 1966 & 1.167 & 565.4 & 1.393 & 333.2 & 1.190 & 739.9 \\
\hline 1967 & 1.210 & 590.7 & 1.462 & 337.8 & 1.240 & 760.4 \\
\hline 1968 & 1.255 & 614.5 & 1.545 & 342.7 & 1.300 & 786.9 \\
\hline 1969 & 1.312 & 640.3 & 1.638 & 348.5 & 1.366 & 812.2 \\
\hline
\end{tabular}

${ }^{28}$ Survey of Current Business, various issues. 
government financial assets, ${ }^{29}$ and assets of cash sickness compensation funds. ${ }^{30}$ Net private claims on the rest of the world include private U.S. assets and investments abroad, less private U.S. liabilities to foreigners. ${ }^{31}$ Private national wealth

TABLE 20-continued

\begin{tabular}{|c|c|c|c|c|}
\hline Year & $\begin{array}{l}\text { Net Claims } \\
\text { on } \\
\text { Governments } \\
\text { and Rest of } \\
\text { World, } \\
\text { Price Index }\end{array}$ & $\begin{array}{l}\text { Net Claims } \\
\text { on } \\
\text { Governments } \\
\text { and Rest of } \\
\text { World, } \\
\text { Quantity Index }\end{array}$ & $\begin{array}{c}\text { Private } \\
\text { National } \\
\text { Wealth, } \\
\text { Price Index }\end{array}$ & $\begin{array}{c}\text { Private } \\
\text { National } \\
\text { Wealth, } \\
\text { Quantity Index }\end{array}$ \\
\hline 1929 & 0.943 & 35.0 & 0.572 & 725.3 \\
\hline 1930 & 0.938 & 36.3 & 0.532 & 736.7 \\
\hline 1931 & 0.881 & 40.0 & 0.475 & 736.3 \\
\hline 1932 & 0.882 & 42.3 & 0.414 & 732.0 \\
\hline 1933 & 0.891 & 44.2 & 0.417 & 714.0 \\
\hline 1934 & 0.955 & 47.3 & 0.450 & 698.2 \\
\hline 1935 & 0.956 & 49.5 & 0.460 & 691.9 \\
\hline 1936 & 0.940 & 53.2 & 0.478 & 693.6 \\
\hline 1937 & 0.947 & 54.6 & 0.504 & 705.4 \\
\hline 1938 & 0.922 & 59.0 & 0.494 & 717.6 \\
\hline 1939 & 0.905 & 63.8 & 0.498 & 720.6 \\
\hline 1940 & 0.883 & 67.8 & 0.511 & 732.8 \\
\hline 1941 & 0.938 & 75.1 & 0.562 & 752.2 \\
\hline 1942 & 1.018 & 108.4 & 0.629 & 787.3 \\
\hline 1943 & 1.010 & 153.7 & 0.653 & 857.8 \\
\hline 1944 & 0.967 & 209.8 & 0.669 & 939.4 \\
\hline 1945 & 0.935 & 255.8 & 0.660 & 1031.0 \\
\hline 1946 & 0.944 & 259.0 & 0.693 & 1096.0 \\
\hline 1947 & 0.934 & 257.2 & 0.763 & 1136.8 \\
\hline 1948 & 0.931 & 253.7 & 0.806 & 1171.4 \\
\hline 1949 & 0.932 & 260.5 & 0.794 & 1211.1 \\
\hline 1950 & 0.951 & 250.9 & 0.835 & 1247.9 \\
\hline 1951 & 0.956 & 249.2 & 0.885 & 1293.0 \\
\hline 1952 & 0.956 & 257.3 & 0.893 & 1337.6 \\
\hline 1953 & 0.966 & 265.9 & 0.899 & 1377.9 \\
\hline 1954 & 0.971 & 275.5 & 0.899 & 1421.6 \\
\hline 1955 & 0.976 & 275.5 & 0.920 & 1460.9 \\
\hline 1956 & 0.984 & 276.0 & 0.954 & 1512.0 \\
\hline 1957 & 0.989 & 282.3 & 0.986 & 1555.0 \\
\hline 1958 & 1.000 & 294.7 & 1.000 & 1594.7 \\
\hline 1959 & 1.014 & 296.6 & 1.029 & 1625.8 \\
\hline 1960 & 1.028 & 298.4 & 1.046 & 1664.0 \\
\hline 1961 & 1.032 & 307.0 & 1.062 & 1698.6 \\
\hline 1962 & 1.042 & 315.3 & 1.093 & 1732.5 \\
\hline 1963 & 1.045 & 321.4 & 1.115 & 1778.5 \\
\hline 1964 & 1.039 & 333.8 & 1.146 & 1825.9 \\
\hline 1965 & 1.044 & 340.9 & 1.178 & 1884.7 \\
\hline 1966 & 1.043 & 353.0 & 1.217 & 1950.4 \\
\hline 1967 & 1.028 & 378.6 & 1.254 & 2026.8 \\
\hline 1968 & 1.023 & 395.4 & 1.299 & 2100.7 \\
\hline 1969 & 1.028 & 399.2 & 1.350 & 2171.5 \\
\hline
\end{tabular}

${ }^{29}$ FFA (1972), p. 56.

${ }^{30}$ We estimate these assets by cumulating the annual surplus in these funds from NIP (1966), Tables 3.8. and 3.9.

${ }^{31}$ Survey of Current Business, various issues. 
in 1958 is presented in Table 18. Private national wealth and its components are presented annually in Table 19.

\subsection{Wealth in Constant Prices}

With geometric decline in efficiency the expression for the value of wealth is:

$$
W_{t}=q_{A, t} K_{t}
$$

For several capital goods the acquisition price $q_{A, t}$ and quantity of capital $K_{t}$ for each capital good can be combined into price and quantity indexes for wealth. Our wealth account for the U.S. private national economy includes tangible assets held by private households and institutions, and by corporate and noncorporate business, and net claims on the government and foreign sectors, including the claims of social insurance funds on general government. We estimate the price and quantity of assets for each of the five sectors by applying Divisia index number formulas to price and quantity data for each class of capital assets held by the sector. We construct price and quantity index numbers for the U.S. private national economy by applying these index number formulas to Divisia price and quantity indexes for the five sectors. Price and quantity indexes of wealth for 1929-1969 are given in Table 20 .

\section{REFERENCES}

Ando, A. and E. C. Brown (1963), "The Impacts of Fiscal Policy," in E. C. Brown et al., Stabilization Policies, Englewood Cliffs, N.J., Prentice-Hall.

Board of Governors of the Federal Reserve System, Federal Reserve Bulletin, various monthly issues.

- (1972), Flow of Funds, Accounts, 1945-1971, Washington, D.C.

Bowen, W. G. and T. A. Finegan (1969), The Economics of Labor Force Participation, Princeton, Princeton University Press.

Bureau of Economic Analysis, Survey of Current Business, various monthly issues.

Christensen, L. R. (1971), "Entrepreneurial Income: How Does it Measure Up?" American Economic Review, Vol. 61, September, pp. 575-585.

Christensen, L. R. and D. W. Jorgenson (1969), "The Measurement of U.S. Real Capital Input, 1929-1967," Review of Income and Wealth, Series 15, December, pp. 293-320.

- - and - (1970), "U.S. Real Product and Real Factor Input, 1929-1967," Review of Income and Wealth, Series 16, March, pp. 19-50.

Council of Economic Advisers (1972), Economic Report of the President, Washington, D.C.

Frane, L. and L. R. Klein (1953), "The Estimation of Disposable Income by Distributive Shares," Review of Economics and Statistics, Vol. 35, November, pp. 333-337.

Goldsmith, R. W. (1951), "A Perpetual Inventory of National Wealth," Studies in Income and Wealth, Vol. 14, New York, National Bureau of Economic Research, pp. 5-61.

- (1955), A Study of Saving in the United States, Princeton, Princeton University Press. (1962), The National Wealth of the United States in the Postwar Period, New York, National Bureau of Economic Research.

(1965), The Flow of Capital Funds in the Postwar Economy, New York, National Bureau of Economic Research.

Goldsmith, R. W., R. E. Lipsey, and M. Mendelson (1963), Studies in the National Balance Sheet of the United States, Princeton, Princeton University Press.

Grose, L., T. Rottenberg, and R. Wasson (1969), "New Estimates of Fixed Business Capital in the United States," Survey of Current Business, Vol. 49, February, pp. 46-52.

Internal Revenue Service, Statistics of Income: Individual Returns, various annual issues.

Kendrick, J. W. (1972), Postwar Productivity Trends in the United States, New York, National Bureau of Economic Research. 
Office of Business Economics (1966), The National Income and Product Accounts of the United States, 1929-1965, A Supplement to the Survey of Current Business, Washington, D.C., U.S. Department of Commerce.

U.S. Department of the Treasury, Treasury Bulletin, various issues. 